Marquette University

e-Publications@Marquette

Biological Sciences Faculty Research and

Publications

Biological Sciences, Department of

2011

\title{
Anolis chrysolepis Duméril and Bibron, 1837 (Squamata: Iguanidae), Revisited: Molecular Phylogeny and Taxonomy of the Anolis chrysolepis Species Group
}

Annelise B. D'Angiolella

Museu Paraense Enilio Goeldi

Tony Gamble

Marquette University, anthony.gamble@marquette.edu

Teresa C. S. Avila-Pires

Museu Paraense Enilio Goeldi

Guarino R. Colli

Universidade de Brasília

Brice P. Noonan

University of Mississippi

See next page for additional authors

Follow this and additional works at: https://epublications.marquette.edu/bio_fac

Part of the Biology Commons

\section{Recommended Citation}

D'Angiolella, Annelise B.; Gamble, Tony; Avila-Pires, Teresa C. S.; Colli, Guarino R.; Noonan, Brice P.; and Vitt, Laurie J., "Anolis chrysolepis Duméril and Bibron, 1837 (Squamata: Iguanidae), Revisited: Molecular Phylogeny and Taxonomy of the Anolis chrysolepis Species Group" (2011). Biological Sciences Faculty Research and Publications. 788.

https://epublications.marquette.edu/bio_fac/788 


\section{Authors}

Annelise B. D'Angiolella, Tony Gamble, Teresa C. S. Avila-Pires, Guarino R. Colli, Brice P. Noonan, and Laurie J. Vitt 


\title{
ANOLIS CHRYSOLEPIS DUMÉRIL AND BIBRON, 1837 (SQUAMATA: IGUANIDAE), REVISITED: MOLECULAR PHYLOGENY AND TAXONOMY OF THE ANOLIS CHRYSOLEPIS SPECIES GROUP
}

\author{
ANNELISE B. D'ANGIOLELLA,${ }^{1}$ TONY GAMBLE, ${ }^{2}$ TERESA C. S. AVILA-PIRES,${ }^{3}$ GUARINO R. COLLI, ${ }^{4}$ \\ BRICE P. NOONAN, ${ }^{5}$ AND LAURIE J. VITT ${ }^{6}$
}

\begin{abstract}
Aвstract. The Anolis chrysolepis species group is distributed across the entire Amazon basin and currently consists of $A$. bombiceps and five subspecies of A. chrysolepis. These lizards are characterized by moderate size, relatively narrow digital pads, and a small dewlap that does not reach the axilla. We used the mitochondrial gene ND2 to estimate phylogenetic relationships among putative subspecies of A. chrysolepis and taxa previously hypothesized to be their close relatives. We also assessed the congruence between molecular and morphological datasets to evaluate the taxonomic status of group members. On the basis of the two datasets, we present a new taxonomy, elevating each putative subspecies of A. chrysolepis to species status. We provide new morphological diagnoses and new distributional data for each species.
\end{abstract}

Key words: Anolis, Amazon, Iguanidae, molecular phylogeny, taxonomy

Resumo. O grupo de espécies Anolis chrysolepis atualmente consiste em A. bombiceps e cinco subespécies de A. chrysolepis, ocupando toda a Bacia Amazônica. Esses lagartos são caracterizados por tamanho moderado, lamelas digitais relativamente estreitas e um papo extensível que não chega às axilas. Nós utilizamos o gene mitocondrial ND2 para estimar as relações filogenéticas entre as subespécies de $A$. chrysolepis e táxons previamente considerados parentes próximos. Nós também determinamos a congruência entre conjuntos de dados morfológicos e moleculares, para avaliar o status taxonômico dos membros desse grupo. Com base nos dois conjuntos de dados, apresentamos uma nova taxonomia, elevando

\footnotetext{
${ }^{1}$ Programa de Pós-Graduação em Zoologia UFPAMPEG, Belém, PA, Brazil. Author for correspondence (annelise.dangiolella@gmail.com).

${ }^{2}$ University of Minnesota, Minneapolis, Minnesota.

${ }^{3}$ Museu Paraense Emílio Goeldi, Belém, PA, Brazil.

${ }^{4}$ Universidade de Brasília, Brasília, DF, Brazil.

${ }^{5}$ The University of Mississippi, University, Mississippi.

${ }^{6}$ University of Oklahoma, Norman, Oklahoma.
}

cada subespécie de A. chrysolepis ao status de espécie. Fornecemos novas diagnoses morfológicas e novos dados de distribuição para cada espécie.

Palavras-chave: Anolis, Amazônia, Iguanidae, filogenia molecular, taxonomia

\section{INTRODUCTION}

The Pleistocene Refuge Hypothesis proposed almost simultaneously by Haffer (1969) and Vanzolini and Williams (1970) posits that patches of lowland tropical forest that existed during dry periods in the Pleistocene served as core areas for speciation in birds and in the lizard complex Anolis chrysolepis, respectively. Although the Pleistocene Refuge Hypothesis has been falsified for members of the A. chrysolepis species group because diversification occurred much earlier (15 mya) than the Pleistocene (Glor et al., 2001), relationships among all members of the group have not been worked out and related taxa (e.g., A. meridionalis and A. bombiceps) have not been properly placed with reference to the A. chrysolepis complex, and current names do not accurately reflect the evolutionary history of the group (Glor et al., 2001; Nicholson et al., 2005). Because the A. chrysolepis species group has been and continues to be a model for evolutionary (Nicholson et al., 2006, 2007; Schaad and Poe, 2010) and ecological (Vitt and Zani, 1996; Vitt et al., 2001, 2008) studies, it is critical that their relationships be properly understood. Here we present a phylogenetic hypothesis for the A. chrysolepis species 
group using a much larger set of samples than was available previously and provide species names for taxa that can be identified as independent evolutionary lineages. Following de Queiroz (2007), we consider independent evolutionary lineages, here recognized on the basis of gene trees, analogous to species. Results of this study should be directly applicable to phylogeographic and phyloecological studies of the A. chrysolepis species group.

The A. chrysolepis group comprises two species: A. chrysolepis Duméril and Bibron, 1837, and A. bombiceps Cope, 1876. Anolis chrysolepis is currently composed of five subspecies: A. chrysolepis chrysolepis, in eastern Guiana (Brazil, French Guiana, Suriname, and southern Guyana); A. chrysolepis planiceps Troschel, 1848, in western Guiana (Brazil, Suriname, northwestern Guyana, Venezuela, and Trinidad); A. chrysolepis scypheus Cope, 1864, in western Amazonia (Colombia, Ecuador, Peru, and northwestern Brazil); A. chrysolepis tandai Avila-Pires, 1995, in southwestern Amazonia (Brazil and Peru); and A. chrysolepis brasiliensis Vanzolini and Williams, 1970, in Brazil, from Maranhão and enclaves of open vegetation in southern Pará south to São Paulo (Vanzolini and Williams, 1970; AvilaPires, 1995; Icochea et al., 2001; SantosJr et al., 2007). Anolis bombiceps occurs in western Amazonia, in Peru, Colombia, and Brazil, at least in partial sympatry with $A$. $c$. scypheus and perhaps also with A. c. tandai (Avila-Pires, 1995). Members of the A. chrysolepis group are characterized by their moderate size (up to $83 \mathrm{~mm}$ snout-vent length); short heads; supraorbital semicircles usually forming a pronounced ridge; relatively narrow digital pads, with distal lamellae under phalanx ii forming a slightly prominent border; a dewlap that does not reach the axilla and is present in both sexes (but smaller in females); and keeled, imbricate ventral scales that are distinctly larger than dorsals.

The A. chrysolepis species group was examined morphologically by Vanzolini and Williams (1970), who recognized four sub- species of A. chrysolepis and a distinct species, A. bombiceps. Vanzolini and Williams (1970: 13) believed the level of differentiation between the subspecies were "closest to species difference, and indicative, perhaps, of past and future potential species formation." Anolis chrysolepis was later examined by Avila-Pires (1995) under the name A. nitens. She described another subspecies, A. n. tandai, and observed that most specimens occurring in areas of intergradation according to Vanzolini and Williams (1970) could be assigned to one of the recognized subspecies.

Very little subsequent taxonomic research has been conducted on the species of the $A$. chrysolepis group. One molecular phylogenetic study included three of the described A. chrysolepis subspecies and found they formed a weakly supported clade (Glor et al., 2001). Glor et al. (2001: 2664) concluded that, "further study of geographical genetic interactions among these subspecies probably will reveal that they are distinct species." Additional molecular phylogenetic research, with broad outgroup sampling, recovered a well-supported clade consisting of $A$. onca, A. annectans, A. lineatus, A. auratus, A. meridionalis, and A. chrysolepis, although A. chrysolepis was represented by just a single individual from Roraima, Brazil (Nicholson et al., 2005). Members of this clade were included in another phylogenetic analysis (Nicholson et al., 2006), using the same three A. chrysolepis subspecies of Glor et al. (2001), which recovered a paraphyletic A. chrysolepis. Nicholson et al. (2006) found that A. c. tandai was more closely related to $A$. meridionalis and the $A$. onca + A. annectans clade, whereas A. c. scypheus and A. c. planiceps formed a clade that was the sister group to the remaining species + A. auratus. Like Glor et al. (2001), Nicholson et al. (2006) stressed the need for additional research into the systematics of $A$. chrysolepis and the possible existence of cryptic species. Anolis bombiceps has not been included in any molecular studies so far.

The name A. chrysolepis has a long and confusing history, with both A. nitens and A. 
chrysolepis considered valid names for the species (Hoogmoed, 1973; Avila-Pires, 1995; Myers and Donnelly, 2008). Myers and Donnelly (2008) presented a detailed history of the use of these names, and Myers (2008) requested the International Commission of Zoological Nomenclature (ICZN) to give precedence of $\mathrm{A}$. chrysolepis Duméril and Bibron, 1837, over Draconura nitens Wagler, 1830, which was accepted (ICZN, 2010).

In the present work, we analyzed mitochondrial DNA from the protein coding gene ND2 and associated tRNA and morphological data from all five described subspecies of A. chrysolepis and related taxa to 1) recover the phylogenetic relationships among subspecies of A. chrysolepis and test previous phylogenetic hypotheses, 2) evaluate the taxonomic status of described subspecies of A. chrysolepis, and 3) present a revised taxonomy that incorporates this phylogenetic information.

\section{MATERIALS AND METHODS}

\section{Taxon Sampling and DNA Sequencing}

We sampled representatives of each of the five subspecies of A. chrysolepis (Table 1, Figure 1). Species previously shown to be closely related to A. chrysolepis were also included either from newly sequenced samples (e.g., A. bombiceps) or from previously published GenBank material (Glor et al., 2001; Nicholson, 2002; Nicholson et al., 2005, 2006). Genomic DNA was extracted from muscle, liver, or tail clips using DNeasy Blood and Tissue Kit (Qiagen, Valencia, California). Polymerase chain reaction was used to amplify portions of the mitochondrial protein-coding gene ND2 (NADH dehydrogenase subunit 2) and adjacent tRNAs with primers LVT_Metf.6_AnCr (AAGCTATTGGGCCCATACC) and LVT_5617_AnCr (AAAGTGYTTGAGTTGCATTCA) (Rodriguez Robles et al., 2007). Polymerase chain reaction cleanup and DNA sequencing was performed by Agencourt Bioscience (Beverly, Massachusetts). Sequences were edited and aligned using SEQUENCHER ver. 4.2 (Gene Codes, Ann Arbor, Michigan). ND2 sequences were translated into amino acids using MacClade ver. 4.08 (Maddison and Maddison, 1992) to confirm alignment and gap placement and ensure there were no premature stop codons.

\section{Phylogenetic Analyses}

We analyzed the ND2 data using parsimony in PAUP ver. 4.0b10 (Swofford, 2001). Parsimony analysis was conducted using a heuristic search with 1,000 random taxon additions and tree bisection and reconnection (TBR) branch swapping and all characters equally weighted. We conducted 1,000 bootstrap replicates with 25 random additions per replicate to assess nodal support (Felsenstein, 1985).

Mitochondrial DNA (mtDNA) has been widely used to recover phylogenetic relationships among species and to delimit species (Avise et al., 1998; Grau et al., 2005; Gamble et al., 2008; Fenwick et al., 2009), and because of its shorter coalescent times, it is considered a good indicator of population history and species limits (Avise et al., 2000; Wiens and Hollingsworth, 2000; Wiens and Penkrot, 2002; Zink and Barrowclough, 2008; Barrowclough and Zink, 2009). However, the high substitution rate of mitochondrial DNA makes saturation, especially at third codon positions, a possible problem for accurate phylogenetic reconstruction (Jukes, 1987; Yoder et al., 1996, Glor et al., 2001, Hudson and Turelli, 2003). One way to minimize the effects of saturation is to use model-based phylogenetic methods like maximum likelihood (ML) and Bayesian analyses (Felsenstein, 1978; Jukes, 1987; Huelsenbeck et al., 2001, Lartillot et al., 2007). Additionally, the use of partitioned model-based analyses, with separate models of molecular evolution for each gene or codon, can minimize phylogenetic error (Bull et al., 1993; Lemmon and Moriarty, 2004; Nylander et al., 2004; Brandley et al., 2005). We conducted Bayesian analyses using MrBayes 3.1.2 


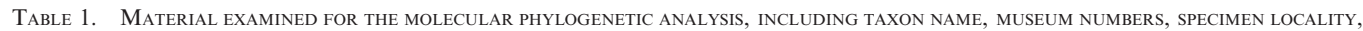
AND GENBANK NUMBERS.

\begin{tabular}{|c|c|c|c|}
\hline Anolis Taxon & ID No. & Locality & GenBank \\
\hline \multirow[t]{7}{*}{ A. tandai } & MPEG 22285 & Itaituba, Pará, Brazil & JN191547 \\
\hline & MPEG 25029 & Juruti, Pará, Brazil & JN191546 \\
\hline & LSUMZ H-14098 & Rio Ituxi, Amazonas, Brazil & JN191542 \\
\hline & MPEG 25060 & Coari, Amazonas, Brazil & JN191545 \\
\hline & LSUMZ H-16398 & Rio Solimões, Amazonas, Brazil & JN191543 \\
\hline & LSUMZ H-16474 & Rio Solimões, Amazonas, Brazil & JN191544 \\
\hline & LSUMZ H-13599 & Rio Juruá, Acre, Brazil & JN191548 \\
\hline \multirow[t]{8}{*}{ A. chrysolepis } & MPEG 26590 & Trombetas, Pará, Brazil & JN191532 \\
\hline & MPEG 26568 & Faro, Pará, Brazil & JN191530 \\
\hline & MPEG 26563 & Acari, Pará, Brazil & JN191531 \\
\hline & BPN780 & Ralleighvallen, Suriname & JN191534 \\
\hline & MPEG 26584 & Maicuru, Pará, Brazil & JN191533 \\
\hline & BPN 1587 & Saul, French Guiana & JN191536 \\
\hline & BPN 1979 & Saul, French Guiana & JN191541 \\
\hline & BPN 1874 & Nouragues, French Guiana & JN191540 \\
\hline \multirow[t]{3}{*}{ A. scypheus } & LSUMZ H-12592 & $\begin{array}{l}\text { Reserva Faunistica Cuyabeno, } \\
\text { Sucumbios Province, Ecuador }\end{array}$ & AF337804 \\
\hline & LSUMZ H-12543 & $\begin{array}{l}\text { Reserva Faunistica Cuyabeno, } \\
\text { Sucumbios Province, Ecuador }\end{array}$ & AF337802 \\
\hline & LSUMZ H-12989 & $\begin{array}{l}\text { Reserva Faunistica Cuyabeno, } \\
\text { Sucumbios Province, Ecuador }\end{array}$ & JN191568 \\
\hline \multirow[t]{5}{*}{ A. planiceps } & LSUMZ H-12300 & Rio Ajarani, Roraima, Brazil & JN227867 \\
\hline & BPN 1080 & Kartabo, Guyana & JN191550 \\
\hline & BPN 1082 & Kartabo, Guyana & JN191549 \\
\hline & BPN 228 & Imbaimadai, Guyana & JN191551 \\
\hline & BPN 96 & Kartabo, Guyana & JN191552 \\
\hline \multirow{11}{*}{ A. brasiliensis } & CHUNB 45077 & Caseara, Tocantins, Brazil & JN191558 \\
\hline & CHUNB 45075 & Minaçú, Goiás, Brazil & JN191559 \\
\hline & CHUNB 08842 & Parauapebas, Pará, Brazil & $\mathrm{JN} 191557$ \\
\hline & CHUNB 43282 & Brasilia, Distrito Federal, Brazil & JN191555 \\
\hline & CHUNB 34542 & Novo Progresso, Pará, Brazil & JN191556 \\
\hline & CHUNB 27158 & Mateiros, Tocantins, Brazil & $\mathrm{JN} 227868$ \\
\hline & CHUNB 11521 & Palmas, Tocantins, Brazil & JN191565 \\
\hline & CHUNB 37528 & São Domingos, Goiás, Brazil & JN191563 \\
\hline & CHUNB 37527 & Paranã, Tocantins, Brazil & JN191562 \\
\hline & CHUNB 52471 & Peixe, Tocantins, Brazil & JN191560 \\
\hline & GRC 16378 & Alto Paraiso, Goiás, Brazil & JN191561 \\
\hline A. auratus & LSMUZ H-13928 & Alter do Chão, Pará, Brasil. & JN191571 \\
\hline A. bombiceps & KU 222145 & $\begin{array}{l}1.5 \mathrm{~km} \mathrm{~N} \text { of Teniente Lopez, Loreto, } \\
\text { Peru }\end{array}$ & JN191570 \\
\hline A. fuscoauratus & LSUMZ H-13566 & Rio Juruá, Acre, Brazil & AF337786 \\
\hline A. meridionalis & LF166692 & $\begin{array}{l}\text { Reserva Mbaracayú, Canindeyu, } \\
\text { Paraguay }\end{array}$ & AY909760 \\
\hline A. lineatus & LSUMZ H-5450 & Netherlands Antilles & AF294287 \\
\hline A. onca & CIEZAH1156 & Estado Falcón, Venezuela & DQ377357 \\
\hline A. annectens & CIEZAH1160 & Estado Falcón, Venezuela & DQ377345 \\
\hline A. sericeus & LACM7069 & Costa Rica & AY909778 \\
\hline A. isthmicus & MFO191 & Mexico & AY909762 \\
\hline A. laeviventris & MVCFC12252 & Guatemala & AY909756 \\
\hline A. sagrei & KdQ1797 & La Habana, Cuba & AF337778 \\
\hline A. utilensis & LDW12480 & Honduras & AY909785 \\
\hline A. grahami & JBL 250 & Discovery Bay, Jamaica & AF055938 \\
\hline A. loveridgei & USNM10683 & Honduras & AY909759 \\
\hline A. uniformis & $\mathrm{n} / \mathrm{a}$ & Belize & AY909784 \\
\hline A. crassulus & MZFC6458 & Mexico & AY909748 \\
\hline A. carolinensis & CCA 8051 & Unknown & NC010972 \\
\hline
\end{tabular}


(Huelsenbeck and Ronquist, 2001) on both the partitioned and unpartitioned datasets. Data were partitioned by codon with a fourth partition for tRNAs and the optimal partitioning strategy selected using Bayes Factors calculated from the harmonic mean likelihood values (Nylander et al., 2004; Brandley et al., 2005). We estimated the best fit model of sequence evolution for the data as a whole and for each partition separately using AIC scores in Modeltest (Posada, 2008). Bayesian analyses were initialized with a neighbor-joining tree and two separate analyses conducted for each partitioning strategy. Each analysis consisted of seven heated chains and one cold chain run for 2 million generations, with sampling every 1,000 generations. Postburnin convergence was checked by visual inspection of likelihood values by generation using Tracer 1.5 (Rambaut and Drummond, 2009) and visual inspection of split frequencies using AWTY (Nylander et al., 2008). We also conducted partitioned Maximum Likelihood analysis, with data partitioned as above using RAXML ver. 7.0.4 (Stamatakis, 2006) using the GTR+GAMMA model for all partitions. We conducted 1,000 "fast bootstrap" replicates and 10 separate maximum likelihood searches. Bootstrap values $\geq 70$ were considered as indicating strong support for both parsimony and ML analyses.

We calculated net among group distances (Nei and Li, 1979) between major lineages of the "A. chrysolepis species group" using MEGA 4 (Kumar et al., 2008). We calculated both uncorrected $p$-distances and corrected distances using the GTR model.

On the basis of our best ML tree, we compared alternative phylogenetic hypotheses using the Shimodaira-Hasegawa $(\mathrm{SH})$ test (Shimodaira and Hasegawa, 1999) and the Approximately Unbiased (AU) test (Shimodaira, 2002). Three alternative hypotheses were considered: 1) monophyly of A. chrysolepis subspecies, excluding $A$. bombiceps and A. meridionalis; 2) monophyly of the A. chrysolepis subspecies $+A$. bombiceps, excluding only A. meridionalis; and 3) monophyly of all A. c. tandai specimens, as identified by morphological data. We used RAxML7.0.4 (Stamatakis, 2006) to compute per-site log likelihoods that were input into CONSEL (Shimodaira and Hasegawa, 2001) to calculate $P$ values. We also tested alternative phylogenetic hypotheses in a Bayesian framework and calculated the Posterior Probabilities of alternative hypotheses using the tree filter option in PAUP*.

\section{Morphological Analyses}

We collected morphological and morphometric data from 403 specimens (Appendix 1) from the following zoological collections: MZUSP, Museu de Zoologia da Universidade de São Paulo; CHUNB, Coleção Herpetológica da Universidade de Brasília; MPEG, Museu Paraense Emílio Goeldi; MCZ, Harvard Museum of Comparative Zoology; and KU, University of Kansas. Measurements were recorded with digital calipers to the nearest $0.1 \mathrm{~mm}$ on the right side of the body, except when specimens were damaged (in this case, the left side was used). Scale and measurement terminology follows Avila-Pires (1995).

We recorded the following morphometric data: snout-vent length (SVL), tail length (from posterior edge of precloacal plate), head width, head height, mouth length (from tip of snout to posterior margin of mouth), distance between orbits (minimum), ear-opening diameter, distance between nostrils (minimum), distance from mouth to ear (from anterior margin of earopening to posterior margin of mouth), snout length (from tip of snout to anterior margin of orbit), interparietal length, tibia length, foot length (from toe IV base to the heel), fourth toe length (from toe IV nail to toe base), and fourth toe maximum width. Additionally, we recorded the following meristic characters: scales around midbody, postrostrals, supralabials, infralabials, loreals (under second canthal), canthals, scales between second canthals, scales between supraorbital semicircles (minimum), scales 
between interparietal and supraorbital semicircles (minimum), postmentals, fourth finger lamellae, and fourth toe lamellae.

A few measurements and scale counts could not be assessed for all specimens analyzed. In multivariate analysis, cases with missing observations will be dropped, weakening the analysis because of loss of information and degrees of freedom. To avoid simply deleting entire rows of data, missing observations can be estimated using a variety of methods, including mean substitution, regression, expectation maximization, maximum likelihood and multiple imputation (Tabachnick and Fidell, 2001; Quinn and Keough, 2002). Among these approaches for imputing values to missing observations, multiple imputation is the most robust and also makes fewer assumptions about the pattern of missing observations (Rubin, 1996; Van Buuren et al., 2006). Therefore, we imputed missing data using multivariate imputations by chained equations (Van Buuren et al., 2006), as implemented by package mice in R v. 2.12.0 (R Development Core Team, 2009).

To partition the total morphometric variation between size and shape variation, we defined body size as an isometric size variable (Rohlf and Bookstein, 1987) following Somers (1986): we calculated an isometric eigenvector, defined a priori with values equal to $p^{-0.5}$, where $p$ is the number of variables (Jolicoeur, 1963), and obtained scores from this eigenvector, hereafter called body size, by postmultiplying the $n$ $\times p$ matrix of log-transformed data, where $n$ is the number of observations, by the $p \times 1$ isometric eigenvector. To remove the effects of body size from the log-transformed data, we used Burnaby's method (Burnaby, 1966): we postmultiplied the $n \times p$ matrix of the log-transformed data by a $p \times p$ symmetric matrix, $\mathbf{L}$, defined as:

$$
\mathbf{L}=\mathbf{I}_{p}-\mathbf{V}\left(\mathbf{V}^{\mathrm{T}} \mathbf{V}\right)^{-1} \mathbf{V}^{\mathrm{T}}
$$

where $\mathbf{I}_{p}$ is a $p \times p$ identity matrix, $\mathbf{V}$ is the isometric size eigenvector defined above, and
$\mathbf{V}^{\mathrm{T}}$ is the transpose of matrix $\mathbf{V}$ (Rohlf and Bookstein, 1987). Hereafter, we refer to the resulting size-adjusted variables as shape variables.

To identify morphometric and meristic variables that best discriminate among species, we used a stepwise discriminant analysis coupled with 100-fold cross-validation to measure classification performance (Quinn and Keough, 2002) using the package klaR in R v. 2.12.0 ( $\mathrm{R}$ Development Core Team, 2009).

\section{RESULTS}

\section{Phylogenetic Analyses}

We sequenced 1,088 base pairs of the mitochondrial ND2 gene and adjacent tRNAs, which contained 82 variable sites and 633 parsimony-informative characters. Thirty-nine new mtDNA sequences from 34 localities (Fig. 1) are reported and aligned with 14 previously published sequences.

A comparison of the partitioned Bayesian analyses to the unpartitioned analyses strongly favored the partitioned strategy (Bayes Factors > 860). We observed convergence among multiple Bayesian runs and utilized post-burnin samples (burnin = $1,000)$ to estimate model parameters and tree topology (Fig. 2). The partitioned ML analysis produced a single tree (Fig. 3, ln $L=-16,649.1489$ ) that had a similar topology to the partitioned Bayesian consensus tree at well-supported nodes. The Parsimony analysis produced 54 equally most parsimonious trees $(\mathrm{TL}=3,832$, CI $=0.337683, \mathrm{RI}=0.682552, \mathrm{RC}=$ 0.230486 , HI $=0.662317$; Fig. 4). Subspecies formed strongly supported monophyletic groups in all analyses, with the exception of specimens of A. c. tandai from Acre. All analyses also recovered a paraphyletic A. chrysolepis with regard to A. bombiceps and A. meridionalis (Figs. 2-4). Sampled individuals of A. chrysolepis, A. bombiceps, and A. meridionalis were members of one of two clades; one (Clade A) composed of A. c. chrysolepis, A. c. tandai, 




Figure 1. Distribution of material examined of A. c. chrysolepis, A. c. scypheus, A. c. tandai, A. c. brasiliensis, A. c. planiceps, A. bombiceps and $A$. meridionalis. Symbols may represent more than one locality.

and Anolis meridionalis and another (Clade B) composed of A. c. brasiliensis, A. c. planiceps, A. c. scypheus, and A. bombiceps. Relationships among taxa in clade B were similar across all trees, with an A. bombiceps + A. c. scypheus clade and an A. c. planiceps + A. c. brasiliensis clade that are sister taxa. Relationships within Clade A varied depending on the analysis. Parsimony analysis recovered A. c. tandai from Acre (LSUMZ H13599) as the sister taxon of the A. $c$. tandai + A. c. chrysolepis clade. The ML and Bayesian trees, on the other hand, recovered the Acre A. c. tandai as the sister taxon of A. c. chrysolepis, but with low bootstrap support. The A. c. chrysolepis + A. c. tandai clade was well supported in all analyses, whereas the A. c. chrysolepis $+A$. c. tandai $+A$. meridionalis clade received poor nodal supported.

Uncorrected pairwise distances among lineages in the A. chrysolepis species group ranged from $5.0 \%$ between $A$. c. tandai and A. c. chrysolepis to $22.1 \%$ between A. c. scypheus and A. meridionalis (Table 2).

Both the SH and AU tests (Table 3) found that the alternative hypothesis of a monophyletic A. chrysolepis, excluding both A. bombiceps and A. meridionalis, resulted in a significantly worse tree than the ML tree. The ML tree constrained to exclude just $A$. meridionalis was not significantly worse than our best ML tree. Similarly, both tests found no significant difference between a tree constraining a monophyletic A. $c$. tandai and our best ML tree. Bayesian Posterior Probabilities of alternative hypotheses showed little to no support (e.g., Posterior Probabilities $<0.05$ ) for a monophyletic A. chrysolepis excluding A. bombiceps and A. meridionalis, as well as a monophyletic A. c. tandai. The Bayesian Posterior Probability of a monophyletic A. chrysolepis + A. bombiceps, excluding A. meridionalis, received moderate support. 




Figure 2. Results of the partitioned Bayesian analysis. a. Phylogeny of the Anolis chrysolepis species group and outgroups. Bayesian posterior probabilities $>0.95$ are indicated by circles at nodes. b. Trace plot of post-burnin log likelihood values for the two Bayesian runs. c. Bivariate plot of the split frequencies for the two Bayesian runs.

\section{Morphological Analyses}

The stepwise discriminant analysis applied on body size and all shape variables selected tibia length, interparietal length, and snout-vent length (all size-adjusted) as the most powerful discriminators of A. chrysolepis spp., A. bombiceps, and A. meridionalis, with a classification accuracy of 0.67 based on cross-validation. The first two linear discriminant functions based on these three variables explained about $99 \%$ of the total variation, the first function mainly representing a contrast between relative tibia length $(-)$ versus relative SVL (+), and the second function repre- senting primarily the variation in interparietal length (Table 4, Fig. 5). Results indicate that $A$. meridionalis and A. $c$. brasiliensis have short tibias and elongate bodies relative to total body size, whereas $A$. c. tandai and A. c. chrysolepis have long tibias and short bodies relative to total body size, and A. bombiceps, A. c. planiceps, and A. c. scypheus have intermediate values of these variables. Additionally, A. c. planiceps has the longest, and A. c. chrysolepis the shortest, interparietal relative to its body size. Morphologically, A. c. chrysolepis and A. c. tandai are very similar, whereas $A$. meridionalis is the most divergent species, 


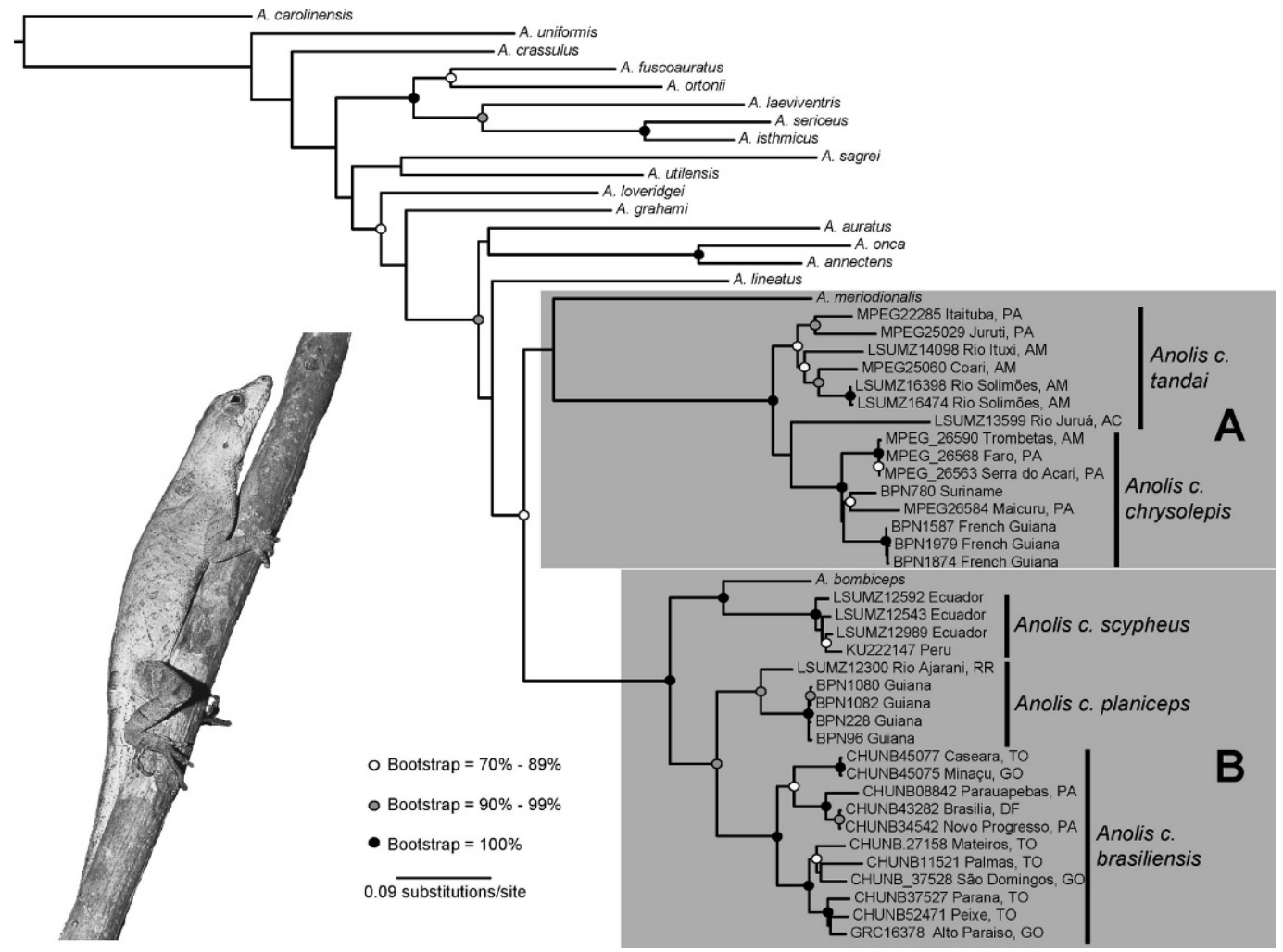

Figure 3. Partitioned Maximum Likelihood phylogeny of the Anolis chrysolepis species group and outgroups. Bootstrap values $>70 \%$ are indicated by circles at nodes. Photo: Anolis brasiliensis from São Domingos, Goiás, Brazil. Tony Gamble.

followed by A. c. brasiliensis. Nevertheless, classification accuracy based on morphology was moderate.

The stepwise discriminant analysis applied on meristic counts selected canthals, fourth toe lamellae, and scales between second canthals as the most powerful discriminators of the species, with a classification accuracy of 0.83 based on cross-validation (Fig. 6). The first two linear discriminant functions based on these three variables explained about $93 \%$ of the total variation. The first function mainly represented a contrast between canthals and scales between second canthals $(-)$ versus fourth toe lamellae (+), whereas the second function primarily represented the variation in fourth toe lamellae and canthals (Table 5, Fig. 6).

Results indicate discrimination 1) in the number of canthals among A. c. planiceps and A. meridionalis (small); A. bombiceps, A. c. tandai, and A. c. chrysolepis (large); and A. c. brasiliensis and A. c. scypheus (intermediate); 2) in the number of fourth toe lamellae among A. c. chrysolepis and A. meridionalis (small); A. c. brasiliensis, A. c. planiceps, and A. c. scypheus (large); and A. bombiceps and A. c. tandai (intermediate); and 3) in the number of scales between second canthals among $A$. meridionalis (few), A. c. scypheus and A. tandai (large), and the remaining species (intermediate). Overall, A. c. chrysolepis, A. c. tandai, and A. bombiceps are more similar, the same happening with $A$. $c$. planiceps, A. brasiliensis, and A. c. scypheus. Anolis meridionalis is the most divergent species. Classification accuracy based on meristic counts was relatively good. 


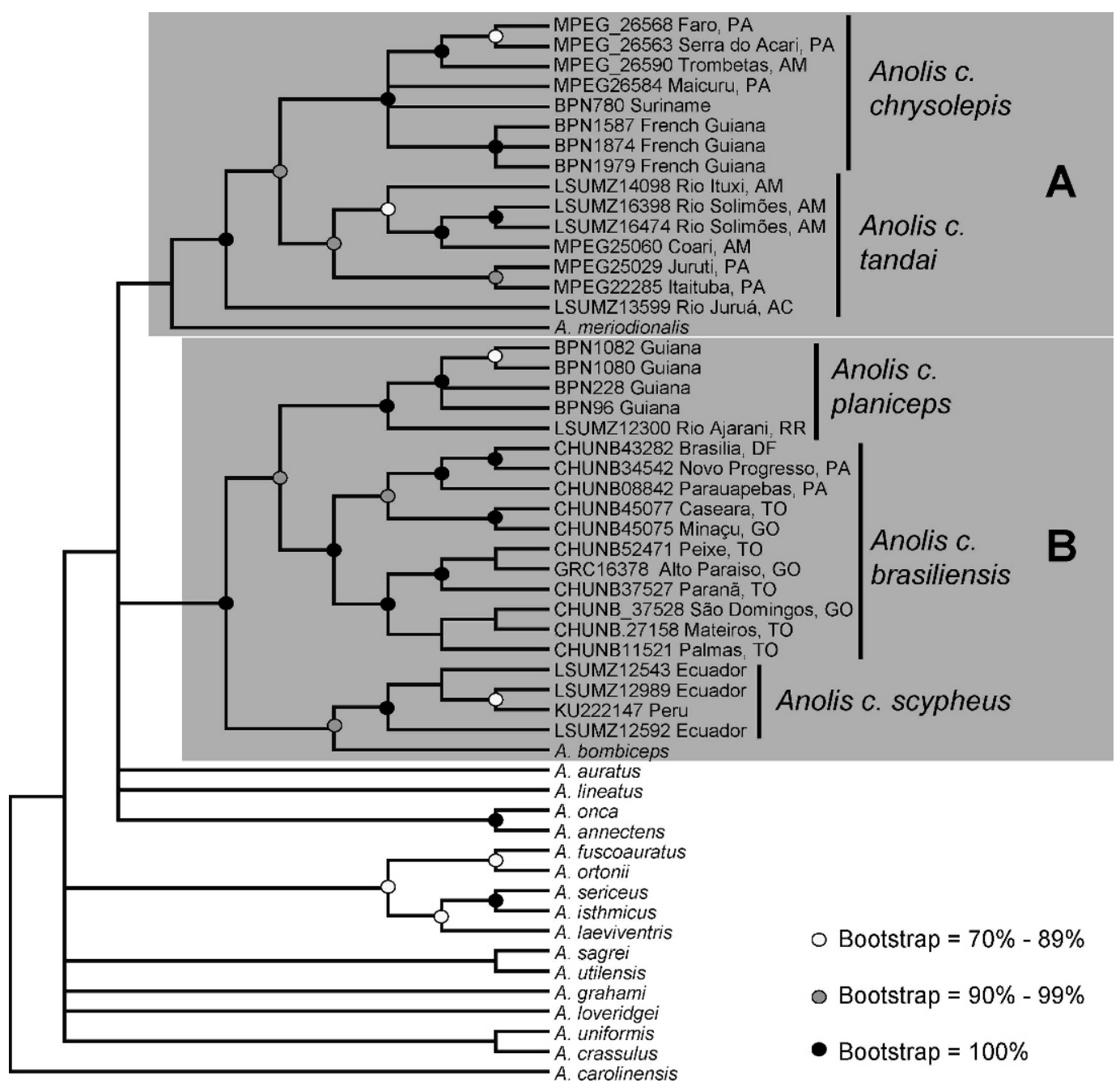

Figure 4. Maximum Parsimony consensus phylogeny of the Anolis chrysolepis species group and outgroups.

TAble 2. Net between group distances for ND2 Among the ANOLIS Chr ySOLEPIS group. Distances Above the diagonal ARe uncorrected P-Distances. Distances Below the diagonal Were maximum liKelihood-CORRected using the GTR Model.

\begin{tabular}{lccccccc}
\hline \hline & $\begin{array}{c}\text { A. c. } \\
\text { chrysolepis }\end{array}$ & $\begin{array}{c}\text { A. c. } \\
\text { tandai }\end{array}$ & $\begin{array}{c}\text { A. c. } \\
\text { planiceps }\end{array}$ & $\begin{array}{c}\text { A. c. } \\
\text { brasiliensis }\end{array}$ & $\begin{array}{c}\text { A. c. } \\
\text { scypheus }\end{array}$ & $\begin{array}{c}\text { A. } \\
\text { bombiceps }\end{array}$ & $\begin{array}{c}\text { A. } \\
\text { meridionalis }\end{array}$ \\
\hline A. c. chrysolepis & - & 0.050 & 0.195 & 0.173 & 0.192 & 0.189 & 0.201 \\
A. c. tandai & 0.059 & - & 0.169 & 0.149 & 0.167 & 0.170 & 0.171 \\
A. c. planiceps & 0.274 & 0.233 & - & 0.076 & 0.128 & 0.136 & 0.193 \\
A. c. brasiliensis & 0.249 & 0.209 & 0.093 & - & 0.114 & 0.121 & 0.193 \\
A. c. scypheus & 0.270 & 0.229 & 0.160 & 0.155 & - & 0.104 & 0.221 \\
A. bombiceps & 0.255 & 0.228 & 0.156 & 0.154 & 0.123 & - & 0.209 \\
A. meridionalis & 0.267 & 0.232 & 0.279 & 0.270 & 0.298 & 0.267 & - \\
\hline
\end{tabular}


Table 3. Comparisons of maximum likelihood (ML) tree scores ( - LNL ) and $P$ Values of the SH and AU tests between our best ML tree and the constrained trees. Bayesian Posterior Probabilities of Alternative hypotheses are also Shown

\begin{tabular}{|c|c|c|c|c|c|}
\hline Hypothesis & $-\ln L$ & $\begin{array}{l}\text { Difference } \\
\quad-\ln L\end{array}$ & $\begin{array}{c}\text { SH } \\
\text { Test }(P)\end{array}$ & $\begin{array}{c}\mathrm{AU} \\
\text { Test }(P)\end{array}$ & $\begin{array}{c}\text { Bayesian Posterior } \\
\text { Probability }\end{array}$ \\
\hline Optimal tree & $-16,900.3198$ & $\mathrm{n} / \mathrm{a}$ & $\mathrm{n} / \mathrm{a}$ & $\mathrm{n} / \mathrm{a}$ & $\mathrm{n} / \mathrm{a}$ \\
\hline $\begin{array}{l}\text { Monophyletic A. chrysolepis } \\
\text { group }\end{array}$ & $-16,963.9620$ & -63.6423 & $<0.001$ & $<0.0001$ & 0.000 \\
\hline $\begin{array}{c}\text { Monophyletic A. chrysolepis } \\
\text { group }+ \text { A. bombiceps } \\
\text { Monophyletic A. c. tandai }\end{array}$ & $\begin{array}{l}-16,900.9392 \\
-16,903.4524\end{array}$ & $\begin{array}{l}-0.6194 \\
-3.1326\end{array}$ & $\begin{array}{l}0.867 \\
0.726\end{array}$ & $\begin{array}{l}0.571 \\
0.420\end{array}$ & $\begin{array}{l}0.219 \\
0.020\end{array}$ \\
\hline
\end{tabular}

\section{DISCUSSION}

The molecular phylogenetic analyses recovered six species-level taxa as part of the A. chrysolepis species group. These taxa can also be morphologically distinguished on the basis of morphometric and meristic characters. Even though we cannot infer relationships among these taxa on the basis of the meristic discriminant analysis, the results of this analysis are consistent with the existence of two clades: one containing $A$. $c$. tandai, A. c. chrysolepis, and A. bombiceps and another clade containing A. c. brasiliensis and A. c. planiceps. Meristic characters in A. c. scypheus appear to be intermediate between these two groups, which is also consistent with it being (together with A. bombiceps) the sister clade to A. c. brasiliensis + A. c. planiceps. Anolis meridionalis was quite distinct from other members of the A. chrysolepis species group on the basis of meristic characters.

We define the A. chrysolepis species group as the clade originating with the most recent common ancestor of A. c. chrysolepis and A. c. brasiliensis. Anolis meridionalis has not historically been allied with the $A$. chrysolepis species group because of its unique morphology. In particular, A. meridionalis differs from other members of the A. chrysolepis species group by having digital dilatations on phalanx ii and iii continuous with scales under phalanx i, instead of forming the prominent border observed in the A. chrysolepis subspecies and A. bombiceps. Although the node leading to the A. chrysolepis species group, including A. meridionalis, was well supported in the ML and Bayesian analyses, the presence of A. meridionalis in clade A received poor support in all phylogenetic analyses. For this reason, we could not reject the alternative hypothesis of a monophyletic A. chrysolepis group exclusive of A. meridionalis. This means that inclusion of $A$. meridionalis in the A. chrysolepis species group is still uncertain. Future phylogenetic analyses that include additional A. meridio-

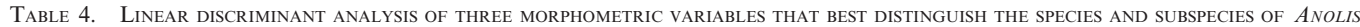
STUDIED. VALUES REPRESENT MEANS OF SCALED, SIZE-ADJUSTED VARIABLES FOR EACH SPECIES AND COEFFICIENTS OF VARIABLES ON FIRST AND SECOND LINEAR DISCRIMINANT FUNCTIONS (LDF 1, LDF 2). PROPORTION OF TOTAL VARIATION EXPLAINED By EACH LDF IN PARENTHESES.

\begin{tabular}{lccc}
\hline \hline Anolis Species & Tibia Length & Interparietal Length & Snout-Vent Length \\
\hline A. bombiceps & 0.57 & -0.35 & 0.78 \\
A. c. brasiliensis & -0.91 & 0.46 & 0.15 \\
A. c. chrysolepis & 0.67 & -1.02 & 0.14 \\
A. meridionalis & -1.67 & 0.58 & 1.46 \\
A. c. planiceps & -0.02 & 0.79 & -0.55 \\
A. c. scypheus & -0.05 & -0.32 & -0.19 \\
A. c. tandai & 0.87 & -0.60 & 0.11 \\
LDF 1 $(0.86)$ & -1.72 & 0.53 & 1.05 \\
LDF 2 (0.13) & -0.60 & -1.11 & 0.49 \\
\hline
\end{tabular}




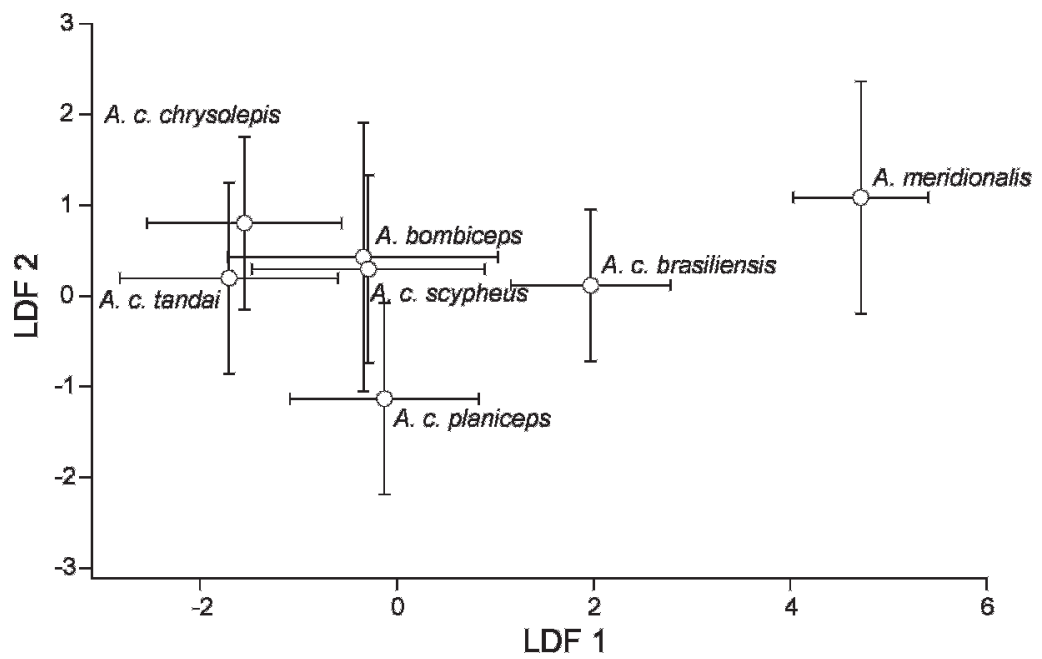

Figure 5. Means (open circles) and standard deviations (error bars) of scores on first (LDF 1) and second (LDF 2) linear discriminant functions of tibia length, interparietal length, and snout-vent length (all size-adjusted; see text for details) for seven subspecies and two species of Anolis.

nalis samples and data from nuclear loci may help resolve this issue.

All described taxa in the molecular analyses formed well-supported, monophyletic groups, with the exception of $A$. $c$. tandai. The A. c. tandai individual from Acre fit the morphological diagnosis we present in this study but was either the sister taxon to A. c. chrysolepis (ML and Bayesian analyses) or the sister taxon to the
A. c. chrysolepis + A. c. tandai clade (parsimony analysis). The apparent paraphyly of A. c. tandai may be due to several phenomena, none of which are mutually exclusive. One possibility is phylogenetic error due to incomplete taxonomic sampling or lack of data (Graybeal, 1998; Mitchell et al., 2000). It is also possible that individuals from the Acre population represent an as yet undescribed, morphologically cryptic



Figure 6. Means (open circles) and standard deviations (error bars) of scores on first (LDF 1) and second (LDF 2) linear discriminant functions of canthals, fourth toe lamellae, and scales between second canthals for seven species of Anolis. 


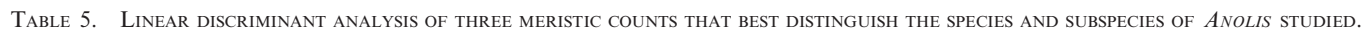
VALUES REPRESENT MEANS OF SCALED VARIABLES FOR EACH SPECIES AND COEFFICIENTS OF VARIABLES ON FIRST AND SECOND LINEAR DISCRIMINANT FUnctions (LDF 1, LDF 2). PRoportion of total VARiation EXPLAined By EACH LDF in PARENTHESEs.

\begin{tabular}{lccc}
\hline \hline Anolis Species & Canthals & Fourth Toe Lamellae & $\begin{array}{c}\text { Scales Between Second } \\
\text { Canthals }\end{array}$ \\
\hline A. bombiceps & 1.13 & -0.63 & -.022 \\
A. c. brasiliensis & -0.09 & 0.72 & -0.67 \\
A. c. chrysolepis & 0.41 & -1.50 & 0.21 \\
A. meridionalis & -0.77 & -1.80 & -1.05 \\
A. c. planiceps & -1.48 & 0.42 & -0.56 \\
A. c. scypheus & 0.09 & 0.56 & 0.99 \\
A. c. tandai & 0.96 & -0.66 & 0.75 \\
LDF 1 $(0.74)$ & -1.38 & 0.92 & -0.69 \\
LDF 2 $(0.18)$ & -0.92 & -1.36 & -0.20 \\
\hline
\end{tabular}

species. Incomplete lineage sorting can also result in discordance between individual gene trees and the species tree because of the retention and/or sorting of ancestral polymorphisms, particularly when populations have diverged recently, have a large effective population size, or both (Maddison, 1997; Ballard and Whitlock, 2004; Maddison and Knowles, 2006). Additional phylogenetic analyses incorporating nuclear genes and additional taxa, as well as using methods that incorporate coalescent processes and incomplete lineage sorting, would be useful in clarifying relationships among A. c. tandai populations.

Our results show broad congruence among molecular and morphological data sets that are consistent with independent evolutionary lineages. Most importantly, each of these lineages is morphologically diagnosable. Genetic distances among sister taxa in the A. chrysolepis group were also comparable to ND2 distances among sister species in other squamate taxa (Macey et al., 1998, 1999; Glor et al., 2001; Oliver et al., 2009). Therefore, we elevate each subspecies to species status under the general lineage species concept (de Queiroz, 1998, 1999, 2005, 2005a, $2005 \mathrm{~b}, 2007)$. To facilitate future studies, each species, including $A$. bombiceps and A. meridonalis, is diagnosed below and an identification key is provided, considering morphological data collected for this study as well as data from the literature. Table 6 compares the main meristic and morphometric characters.

\section{Taxonomy/Species Accounts}

All descriptions of color pattern are based on literature, photographs of live animals, and preserved specimens.

\section{Anolis chrysolepis Duméril and Bibron, 1837.}

Anolis chrysolepis Duméril and Bibron, 1837:94 (lectotype MHNP 2456, type locality: La Mana, French Guiana); Cunha, 1961:60; Peters and DonosoBarros, 1970:61; Avila Pires et al., 2010:94.

Anolis chrysolepis chrysolepis; Vanzolini and Williams, 1970:85; Hoogmoed, 1973:112; Hoogmoed and Avila-Pires, 1989:168.

Norops nitens chrysolepis; Savage and Guyer, 1991:366.

Anolis nitens chrysolepis; Avila-Pires, 1995:75.

Abbreviated Description. Maximum SVL $74 \mathrm{~mm}$. Vertebral region with distinctly enlarged scales, middorsal row largest; number of rows of enlarged scales increases posteriorly. Scales on upper arms smaller than, to subequal to, vertebral scales. Supraorbital semicircles with scarcely enlarged scales. Supraocular scales keeled, slightly larger than or subequal to scales 
TABLE 6. COMPARISONS OF MERISTIC CHARACTERS, BODY PROPORTIONS AND MEASUREMENTS (IN MILLIMETERS) AMONG THE SPECIES OF MEMBERS OF THE ANOLIS CHRYSOLEPIS GROUP.

\begin{tabular}{|c|c|c|c|c|c|c|c|}
\hline Character* & $\begin{array}{c}\text { A. } \\
\text { chrysolepis }\end{array}$ & $\begin{array}{c}\text { A. } \\
\text { tandai }\end{array}$ & $\begin{array}{c}\text { A. } \\
\text { scypheus }\end{array}$ & $\begin{array}{c}\text { A. } \\
\text { planiceps }\end{array}$ & $\begin{array}{c}\text { A. } \\
\text { brasiliensis }\end{array}$ & $\begin{array}{l}\text { A. } \\
\text { bombiceps }\end{array}$ & $\begin{array}{l}\text { A. } \\
\text { meridionalis }\end{array}$ \\
\hline No. of specimens & 50 & 96 & 49 & 72 & 116 & 11 & 9 \\
\hline $\max . \operatorname{svl}(\mathrm{mm})$ & 74 & 70 & 80 & 76 & 69 & 74 & 56 \\
\hline midbody & $101-156$ & $91-150$ & $110-174$ & $110-149$ & $112-155$ & $125-137$ & $79-106$ \\
\hline midbody median and & $123.18 \pm$ & $134.06 \pm$ & $145.94 \pm$ & $125.84 \pm$ & $129.12 \pm$ & $131.37 \pm$ & $92.22 \pm$ \\
\hline $\begin{array}{l}\text { standard deviation } \\
\text { values }\end{array}$ & 12.8 & 7.43 & 14.59 & 9.46 & 10.78 & 3.08 & 9.39 \\
\hline slabials & $11-15$ & $10-14$ & $10-14$ & $10-14$ & $10-13$ & $10-12$ & $9-11$ \\
\hline ilabials & $11-15$ & $10-14$ & $10-13$ & $9-11$ & $8-12$ & $10-13$ & $8-11$ \\
\hline prostrals & $4-7$ & $5-9$ & $5-7$ & $4-7$ & $5-7$ & $5-6$ & 5 \\
\hline loreals & $5-10$ & $5-9$ & $7-10$ & $6-9$ & $6-10$ & $6-7$ & $6-7$ \\
\hline canthals & $6-10$ & $6-11$ & $6-11$ & $6-8$ & $5-9$ & $9-11$ & $5-6$ \\
\hline scales bet $2^{\text {a }}$ canthals & $9-14$ & $10-15$ & $9-15$ & $8-14$ & $8-14$ & $9-12$ & $8-10$ \\
\hline $\begin{array}{l}\text { scales bet } \\
\text { semicirsorbits }\end{array}$ & $1-4$ & $1-4$ & $1-5$ & $1-3$ & $0-3$ & $1-3$ & $0-1$ \\
\hline interp-semicirsorbit & $1-5$ & $2-4$ & $2-5$ & $1-3$ & $1-4$ & $2-4$ & $0-2$ \\
\hline pmentals & $4-8$ & $4-8$ & $4-8$ & $4-8$ & $4-8$ & $6-8$ & $5-8$ \\
\hline lam-4fg & $12-17$ & $14-19$ & $15-21$ & $14-20$ & $15-20$ & $15-19$ & $10-12$ \\
\hline lam-4toe & $18-26$ & $20-28$ & $26-35$ & $19-34$ & $25-32$ & $21-29$ & $18-24$ \\
\hline tail/svl & $1.15-2.17$ & $1.48-2.42$ & $1.66-2.53$ & $1.33-3.27$ & $1.22-2.54$ & $1.69-2.18$ & $1.97-2.38$ \\
\hline mouth/svl & $0.13-0.25$ & $0.19-0.24$ & $0.18-0.24$ & $0.19-0.26$ & $0.18-0.26$ & $0.19-0.21$ & $0.19-0.21$ \\
\hline interp/head-w & $0.07-0.19$ & $0.08-0.24$ & $0.11-0.25$ & $0.16-0.32$ & $0.11-0.30$ & $0.10-0.28$ & $0.16-0.30$ \\
\hline tibia/svl & $0.20-0.38$ & $0.30-0.43$ & $0.26-0.38$ & $0.27-0.36$ & $0.26-0.34$ & $0.29-0.36$ & $0.22-0.27$ \\
\hline Interpatietal & $0.64-1.65$ & $0.84-2.22$ & $0.81-2.37$ & $0.98-2.79$ & $0.92-2.65$ & $1.1-2.9$ & $1.28-2.07$ \\
\hline head-w & $5.93-10.5$ & $5.31-11.41$ & $5.67-13.08$ & $4.95-12.14$ & $7.25-11.75$ & $8.96-10.73$ & $6.95-8.07$ \\
\hline head-alt & $5.00-8.39$ & $4.33-9.65$ & $4.23-11.02$ & $3.28-9.39$ & $5.56-9.2$ & $7.62-8.33$ & $4.88-6.36$ \\
\hline orbdist & $4.01-6.39$ & $3.4-7.19$ & $3.04-8.31$ & $3.31-8.41$ & $4.39-7.26$ & $6.09-6.65$ & $4.02-4.86$ \\
\hline eardiam & $0.40-1.41$ & $0.75-1.89$ & $0.40-2.23$ & $0.47-1.71$ & $0.87-2.00$ & $0.88-1.68$ & $0.84-1.09$ \\
\hline nostrilsdis & $1.25-2.37$ & $1.14-2.7$ & $1.10-2.95$ & $1.07-2.76$ & $1.40-2.82$ & $2.0-2.36$ & $1.42-1.73$ \\
\hline mouth to ear & $1.13-3.03$ & $1.6-2.92$ & $1.09-3.09$ & $1.06-3.52$ & $0.96-2.72$ & $1.47-2.18$ & $1.28-1.53$ \\
\hline snout & $2.97-6.69$ & $3.35-7.00$ & $2.78-7.72$ & $2.69-7.17$ & $3.92-8.14$ & $4.67-6.46$ & $4.8-5.82$ \\
\hline $\max$. toe IV & 20.94 & 24.42 & 26.91 & 28.31 & 21.63 & 25.51 & 14.12 \\
\hline $\max$. foot & 25.63 & 30.24 & 31.46 & 31.89 & 26.48 & 22.66 & 17.39 \\
\hline toe IV width & $0.55-1.30$ & $0.47-1.29$ & $0.61-1.48$ & $0.51-1.46$ & $0.92-1.65$ & $0.96-1.26$ & $0.61-0.91$ \\
\hline
\end{tabular}

* Abbreviations: max. svl = maximun snout-vent length; midbody = number of scales around midbody; slabials = total number of supralabials; ilabials = total number of infralabials; prostrals = total number of postrostrals; scales bet $2^{\mathrm{a}}$ canthals = number of scales on the snout between the second canthals; scales bet semicirsorbits $=$ minimum number of scales between supraorbital semicircles; interp-semicirsorbit $=$ minimum number of scales between any of the supraorbital semicircles and interparietal; pmentals $=$ number of postmentals; lam- $4 \mathrm{fg}=$ number of expanded lamellae under the fourth finger; lam- 4 toe $=$ number of expanded lamellae under fourth toe; tail/svl, mouth/svl, tibia/svl = respectively, the rates of the tail, mouth, and tibia length with the snout-vent length; interp/ head- $\mathrm{w}=$ the rate of interparietal width with head width; interparietal = interparietal width; head-w = head width; head-alt = head height; orbdist = minimum

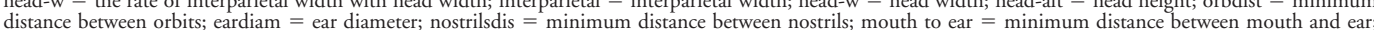
distance between orbits; eardiam = ear dister; nostrilsdis = minimum distance between nostrils; mouth to ear $=$ minimum distance between mouth and ear; snout $=$ from the tip of snout
IV width $=$ fourth toe width.

on snout, grading into granules laterally and posteriorly. Interparietal subequal to or slightly larger than adjacent scales (Fig. 7A, B).

Color in Preservative. Color pattern sexually dimorphic. Male dorsal color pale or grayish-brown with or without a wide light vertebral band bordered by a grayishbrown irregular band laterally. Paired triangular spots may be present along back; most specimens with paired triangular spots on sacral region. Female dorsal pattern less variable. A thin dark brown line begins at posterior corner of each eye at each side, converging toward neck and continuing along the body, where they delimit a lighter or plumbeous vertebral band that darkens and expands laterally on tail.

Dewlap Color in Life and Preservative. In preservative, male dewlap skin royal blue, dark blue, or blackish, with light scales or blue scales toward rim. Female dewlap cream, similar to surrounding area; scales may be darker at edge. In life, male dewlap skin usually royal blue or blackish blue with 


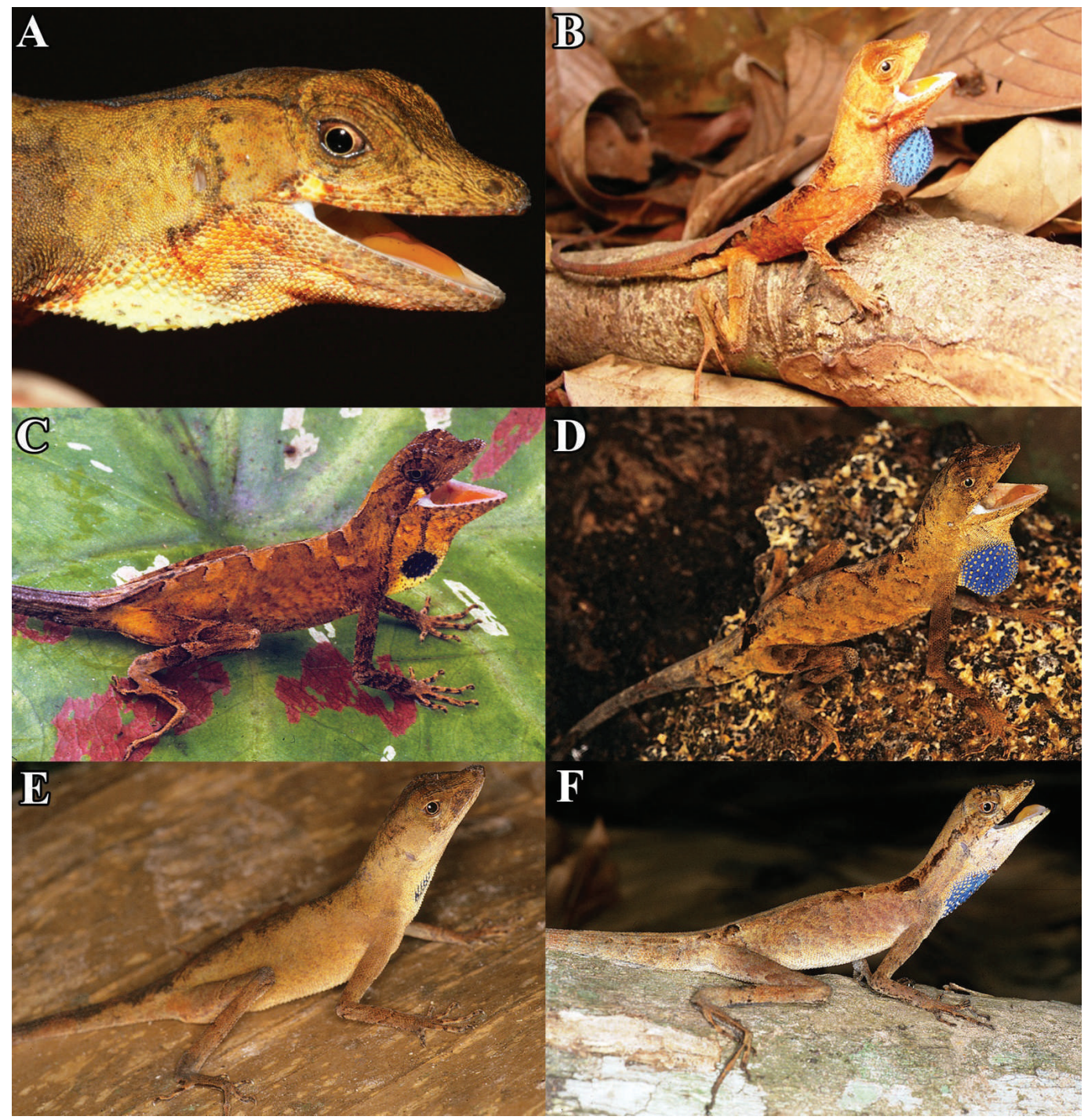

Figure 7. Anolis chrysolepis species group. A) Anolis chrysolepis female from Nassau Plateau, Suriname (Photo: Robert Langstroth), B) Anolis chrysolepis male from Faro, Pará, Brazil (Photo: Waldima Rocha), C) Anolis tandai female from Rio Juruá Acre (Photo: Laurie J. Vitt), D) Anolis tandai male from Rio Juruá, Acre, Brazil (Photo: Laurie J. Vitt), E) Anolis tandai female from Rio Ituxi, Amazonas, Brazil (Photo: Laurie J. Vitt), F) Anolis tandai male from Amazonas, Brazil (Photo: Laurie J. Vitt).

light scales or blue scales along rim. AvilaPires (1995) mentioned a cobalt-blue juvenile male dewlap (RMNH 24673) with white to orange scales, surrounded by a spectrum-orange area that extended through most of ventral surface of head. Female dewlap skin usually yellowish to orange with gray or cream scales; an orange lateral area extended through most of ventral surface of head may be present. Hoogmoed and Avila-Pires (1991) mentioned a female from French Guiana with yellow dewlap with orange scales, presenting a bluish area toward the rim.

Comparison with Other Species from the A. chrysolepis Species Group. This species 
has proportionally the smallest interparietal length among the species of the group (Table 6). It differs from its sister taxon A. tandai mainly by a lower number of postrostral scales (4-7 in A. chrysolepis and 5-9 in A. tandai) and by female dewlap color, generally cream in A. chrysolepis; cream with a large central blue spot in $A$. tandai.

Distribution. Southern Guyana, Suriname, French Guiana and northern Brazil, in the states of Amapá and Pará.

Anolis tandai Avila-Pires, 1995.

Anolis chrysolepis; Vanzolini, 1986:18;

Gascon and Pereira, 1993:181.

Anolis nitens tandai Avila-Pires, 1995:80

(holotype MPEG 15850, type locality: Rio

Urucu, Amazonas state, Brazil); Icochea

et al., 2001:140; Vitt et al., 2001:401;

Santos-Jr et al., 2007:9; Avila-Pires et al., 2009:116.

Abbreviated Description. Maximum SVL $70 \mathrm{~mm}$. Vertebral region with slightly enlarged scales; number of rows of enlarged scales increases posteriad. Scales on upper arms smaller than, or subequal to, vertebral scales. Supraorbital semicircles with scarcely enlarged scales. Supraocular scales weakly to distinctly keeled, approximately same size as scales on snout, laterally and posteriorly grading into granules, anteriorly surrounded by smaller scales. Interparietal moderately small, larger than adjacent scales (Fig. 7C-F).

Color in Preservative. Color pattern sexually dimorphic. In males, vertebral region usually distinct from flanks, with unclear limits between these areas. A pair of subtriangular dark spots present on sacral region. Some specimens may present sinuous lines, assuming subtriangular shapes along dorsum. Females usually with a welldelimited vertebral band, similar to Anolis chrysolepis females; occasionally dorsal pattern similar to males.

Dewlap Color in Life and Preservative. In preservative, male dewlap royal blue or blackish-blue with light scales. Female dewlap with central blue spot surrounded by a cream area; scales usually light colored. In life, male dewlap skin frequently blue or blackish, with light scales. Avila-Pires (1995) mentioned the dewlap in MPEG 15986 as "ultramarine with cream-color scales on rim." Dewlap in females, when extended, presents a large and central blue spot, surrounded by a cream area. Scales are frequently cream to orange. When not extended, dewlap presents a light rim and is blue laterally. Avila-Pires (1995) described the holotype MPEG 15850 female dewlap color as "sulphur-yellow with a large indigo-blue spot."

Comparison with Other Species from the A. chrysolepis Species Group. As already mentioned by Avila-Pires (1995), this species has the longest tibia in relation to SVL (0.30-0.43). For differences with A. chrysolepis, see above. Avila-Pires (1995) also mentioned the possible sympatry with $A$. bombiceps, which also has a blue or blackish blue dewlap (with no sexual dimorphism), but they can be distinguished by female dewlap color (a central blue spot, surrounded by a pale area in A. tandai), by the minimum number of scales between supraorbital semicircles (1-4 in A. tandai and 1-2 in $A$. bombiceps) and by the number of postmentals (4-8 in A. tandai and 6-8 in A. bombiceps).

Distribution. South of the Amazon River and west of the Tapajós River, in Brazil (states of Pará, Amazonas, Rondônia, Acre, and north of Mato Grosso), and in Peru.

\section{Anolis planiceps Troschel, 1848.}

Anolis planiceps Troschel, 1848:649 (holotype ZMB 529, type locality: Caracas, Venezuela).

Anolis chrysolepis planiceps; Vanzolini and Williams, 1970:85; Hoogmoed, 1973: 125; Myers and Donnelly, 2008:100.

Anolis chrysolepis; Beebe, 1944:97; O'Shea, 1989:69; Zimmerman and Rodrigues, 1990:449; Martins, 1991:182.

Anolis eewi Roze, 1958:311 (holotype FMNH 74040, type locality: Chimantatepui, Bolívar, Venezuela). 


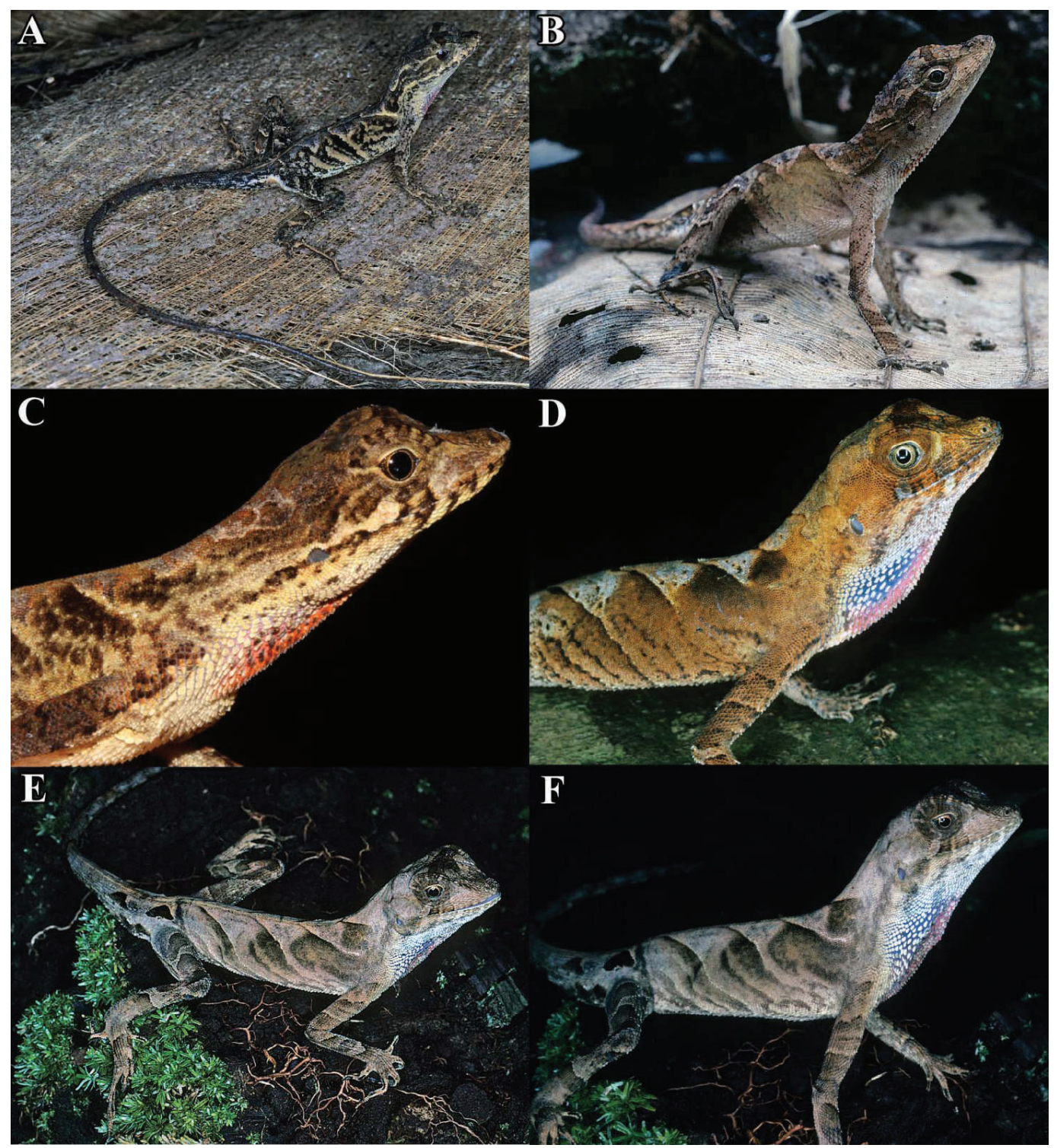

Figure 8. Anolis chrysolepis species group. A) Anolis planiceps from Roraima, Brazil (Photo: Laurie J. Vitt), B) Anolis planiceps from Guatopo, Venezuela (Photo: Laurie J. Vitt), C) Anolis planiceps from Cuyuni-Mazaruni, Guyana (Photo: Robert Langstroth),

D) Anolis scypheus from Ecuador (Photo: Laurie J. Vitt), E) Anolis scypheus from Ecuador (Photo: Laurie J. Vitt), F) Anolis scypheus from Ecuador (Photo: Laurie J. Vitt).

Anolis nitens: Boulenger, 1885:91; Beebe, 1944:200.

Norops nitens nitens; Savage and Guyer, 1991:366.

Anolis nitens nitens; Avila-Pires, 1995:70; Vitt et al., 2008:84.
Abbreviated Description. Maximum SVL $76 \mathrm{~mm}$. Double row of enlarged vertebral scales extending from nape to base of tail; few to several rows of weakly keeled scales, increasing in number caudally, forming a gradual transition between double row of enlarged scales and 
granules on flanks. Scales of upper arms markedly larger than vertebral scales. Supraorbital semicircles with enlarged scales, forming pronounced ridge in some specimens. Supraocular region with distinct group of enlarged, weakly keeled, scales surrounded by smaller scales. Interparietal distinctly larger than adjacent scales (Fig. 8A-C).

Color in Preservative. No sexual dimorphism in color pattern. Specimens usually have many chevrons along back, with tips directed posteriorly, sometimes forming the posterior border of rhomboid figures. A pair of triangular spots commonly present on sacral region. Myers and Donnelly (2008) described the color pattern of two adult males and one adult female as "orange with white or grayish white scales in basal rows, scales darker gray or blackish gray in distal rows."

Dewlap Color in Life and Preservative. Dewlap red, fading rapidly in preserved specimens, appearing cream-white, with light scales. A lateral lavender area may be present as mentioned by Avila-Pires (1995). In life, dewlap skin orange to reddish with grayish to cream scales. Myers and Donnelly (2008) found variation in the dewlap of four juveniles, including a female that had "a large bluish black basal spot on the dewlap, which had a bright orange periphery and mostly white scales (only a few dark scales)."

Comparison with the Other Species from the A. chrysolepis Species Group. This species has the proportionately largest interparietal scale. It differs from its sister taxon A. brasiliensis mainly by dewlap color (red in A. planiceps and blue or grayish/ blackish blue in A. brasiliensis) and body size (A. planiceps reaches $76 \mathrm{~mm}$, whereas A. brasiliensis reaches $69 \mathrm{~mm}$ ).

Distribution. Venezuela, Trinidad, Guyana, and the states of Roraima and Amazonas on the northern part of Brazil.

\section{Anolis brasiliensis Vanzolini and Williams, 1970.}

Anolis chrysolepis; Amaral, 1937:1722.

Anolis chrysolepis brasiliensis; Vanzolini and Williams, 1970:85 (holotype MZUSP
10319, type locality Barra do Tapirapés, Mato Grosso, Brazil); Williams and Vanzolini, 1980:99; Vanzolini, 1981:253, 1986:3; Cunha et al., 1985:23.

\section{Norops nitens brasiliensis; Savage and} Guyer, 1991:366.

Anolis nitens brasiliensis; Avila-Pires, 1995:70; Werneck and Colli, 2006:1987.

Abbreviated Description. Maximum SVL $69 \mathrm{~mm}$. Double row of enlarged vertebral scales from nape to base of tail; few to several rows of dorsal scales with weak keels, increasing in number caudally, gradually transitioning between double row of enlarged scales and granules on flanks. Scales of upper arms markedly larger than vertebral scales. Scales on snout from moderately keeled to smooth, heterogeneous in size, with no distinction between anterior and posterior scales. Supraorbital semicircles with enlarged, generally smooth scales. Supraocular region with most scales large and weakly keeled, surrounded by small scales. Interparietal distinctly larger than adjacent scales (Fig. 9A-D).

Color in Preservative. No sexual dimorphism in color pattern. Dorsal color grayishbrown or pale white, either uniform or not. A light vertebral band may be present, either narrow with undefined margins or wide; in both cases surrounded by darker area. A pair of triangular spots on sacral region commonly present, may be accompanied by second pair at the base of tail. Ventral region usually pale-white, may be marbled with brown spots.

Dewlap Color in Life and Preservative. Dewlap blue or grayish-blue, with light or grayish scales. In life, dewlap usually grayish blue or blackish blue, with dark scales varying from light-cream to dark gray. Some specimens from Tocantins state show the dewlap skin grayish-green tending to yellowish-beige along rim, with scales grayishbrown or pale-cream tending to brownish along rim. Some irregular light-blue lines may be present (Fig. 8D). Vanzolini and Williams (1970) do not describe the dewlap color but refer to the frontispiece plate 




Figure 9. Anolis chrysolepis species group. A) Anolis brasiliensis from Cantão, Tocantins, Brazil (Photo: Laurie J. Vitt), B) Anolis brasiliensis from Cantão, Tocantins, Brazil (Photo: Laurie J. Vitt), C) Anolis brasiliensis from Barra do Ouro, Tocantins, Brazil (Photo: Itamar Tonial), D) Anolis brasiliensis from Jalapão, Tocantins, Brazil (Photo: Laurie J. Vitt), E) Anolis bombiceps from Peru (Photo: Young Cage), F) Anolis meridionalis from Tocantins, Brazil (Photo: Itamar Tonial).

representing the dewlap color in life of a male as green with a brown edge along rim. Avila-Pires (1995) observed in specimens from Carajás, Southern Pará, "a blue dewlap, lighter in females, with scales varying from light to dark gray or cream and the surrounding area may be chrome-orange."

Comparison with the Other Species from the A. chrysolepis Species Group. Anolis brasiliensis, along with A. bombiceps, has the largest toe IV among the other species of the A. chrysolepis group. Anolis brasiliensis differs from A. planiceps, mainly by dewlap color (red in A. planiceps and blue or grayish/blackish blue in A. brasiliensis) and body size (A. planiceps reaches $76 \mathrm{~mm}$, whereas A. brasiliensis reaches $69 \mathrm{~mm}$ ). Anolis brasiliensis is broadly sympatric with 
A. meridionalis, although they occur in different habitats (see A. meridionalis description below) and they differ mainly by digital dilatations under phalanx ii and iii that form a prominent border in A. brasiliensis.

Distribution. Brazil, in southern Pará, Tocantins, Piauí, Maranhão, Ceará, Goiás, Mato Grosso, Minas Gerais, São Paulo, and Distrito Federal.

Two individuals housed in MCZ under the numbers R-60580 and R-60581 are labeled as paratypes of A. c. brasiliensis but have as localities Rio Juruá, Brazil, and Loreto, Peru, respectively. Vanzolini and Williams (1970) did not mention those individuals, which mean that they are not paratypes. Moreover, even though they have typical A. brasiliensis characteristics, it is extremely unlikely that the species occurs in these localities. Given their questionable data, we did not consider these individuals in the morphological analyses or elsewhere in this study.

Anolis scypheus Cope, 1864.

Anolis chrysolepis; Guichenot, 1855:15.

Anolis scypheus Cope, 1864:172 (holotype BM 1946.8.855, type locality: "Caracas" according to Boulenger, 1885, but considered an error by Vanzolini and Williams, 1970:85); Boulenger, 1885:90; Goeldi, 1902:16, 32; Cunha, 1961:67; Peters and Donoso-Barros, 1970:66.

Anolis incompertus incompertus Barbour, 1932:99 (holotype MCZ 32309, type locality: Villavicencio, Meta, Colombia).

Anolis chrysolepis scypheus: Vanzolini and Williams, 1970:85; Vanzolini, 1986:3.

Norops nitens scypheus; Savage and Guyer, 1991:366.

Anolis nitens scypheus; Avila-Pires, 1995: 78.

Abbreviated Description. Maximum SVL $80 \mathrm{~mm}$. Vertebral scales forming double row of enlarged dorsals along back. Scales of upper arms small relative to other species, larger than vertebral scales. Scales on snout relatively small, with raised surface. Supraorbital semicircles with enlarged scales, generally forming pronounced ridge. A small group of enlarged supraocular scales, grading into granules posteriorly and laterally, anteriorly surrounded by smaller scales. Interparietal distinctly larger than surrounded scales (Fig. 8D-F).

Color in Preservative. No sexual dimorphism in color pattern. Dorsum usually with caudally directed chevrons that may form the posterior border of rhomboid figures, similar to the pattern described for $A$. planiceps; or, it may show a broad band with lateral expansions (narrower at nape, extending caudally). A pair of subtriangular dark spots may be present on sacral region.

Dewlap Color in Life and Preservative. Dewlap color in preservative usually pale along rim with pale-cream or blackish scales, and blue with light scales in the center (Fig. 7). In life, dewlap skin red along rim (the red color vanishes very easily in preserved specimens) with red or blackish scales, and blue with pale-cream or lightbrown scales laterally. Avila-Pires (1995) described the dewlap color of $\mathrm{RMNH}$ 24653 as "cobalt-blue with red rim, scales white with orange center."

Comparison with the Other Species from the A. chrysolepis Species Group. Anolis c. scypheus presents the proportionally maximum values of head width, head height, ear diameter, minimum distance between nostrils and SVL among all species of the $A$. chrysolepis species group. For differences with A. bombiceps, see A. bombiceps diagnosis below.

Distribution. Amazonian Colombia, Ecuador, Peru, and the northwestern part of Amazonas state in Brazil.

\section{Anolis bombiceps Cope, 1876.}

Anolis bombiceps Cope, 1876:168 (type apparently lost, type locality: Nauta, Peru); Goeldi, 1902:16, 32; Peters and Donoso-Barros, 1970:49; Vanzolini and Williams, 1970:86; 1986:28; Avila-Pires, 1995:54. 
Norops bombiceps; Savage and Guyer, 1989:110.

Abbreviated Description. Maximum SVL $74 \mathrm{~mm}$. Vertebral scales not or only slightly enlarged. Scales on upper arm subequal to, or slightly larger than, vertebral scales. Scales on snout anteriorly small, weakly to distinctly keeled, posteriorly larger, flat, usually uni- or multicarinated. Supraorbital semicircles with enlarged, keeled scales, forming pronounced ridge. Supraocular region with a group of distinctly enlarged scales surrounded posteriorly and laterally by granules. Interparietal scale distinctly larger than adjacent scales (Fig. 9E).

Color in Preservative. No sexual dimorphism in color pattern. Dorsal color usually brown, with irregular dark spots between hind limbs and irregular figures across limbs. V-shaped lines along back, with apex directed posteriorly, may be present.

Dewlap Color in Life and Preservative. Dewlap deep blue or blackish in preservative, with light or dark scales. In life, dewlap skin deep blue with light or dark scales.

Comparisons with the Other Species from the A. chrysolepis Species Group. Anolis bombiceps is sympatric with A. scypheus and may be sympatric with A. tandai, of which it can be distinguished by dewlap color (deep blue or blackish in A. bombiceps, blue on central region and red along rim in A. scypheus, and blue on central region and cream along rim on females of $A$. tandai; males of A. tandai and A. bombiceps have similar dewlap colors), number of loreals (6-7 in A. bombiceps, 5-9 in A. tandai, and 7-10 in A. scypheus), number of scales between the second canthals (9-12 in A. bombiceps, $10-15$ in A. tandai, and 9-15 in A. scypheus), number of scales between supraorbital semicircles (1-2 in A. bombiceps, 1-4 in A. tandai, and 1-5 in A. scypheus) and postmentals (6-8 in A. bombiceps and 4-8 in A. tandai and A. scypheus).

Distribution. Amazonian Colombia, Ecuador, and Peru and in the State of
Amazonas, Brazil. In this study, we reported A. bombiceps from two Brazilian localities, both in Amazonas state: Apuí, very close to the Colombian border and São Gabriel da Cachoeira.

Anolis meridionalis Boettger, 1885.

Anolis meridionalis Boettger, 1885a:437 (holotype lost, original type locality: Paraguay; neotype MNHN Paraguay 6608, type locality: Colonia Ybycui, Estancia Ybycui, Departamento Canindeyú, Paraguay, according to designation by Motte and Cacciali, 2009); Vanzolini and Williams, 1970:8; Peters and Donoso-Barros, 1970:60; Motte and Cacciali, 2009:19; Langsthroth, 2006:154; Nicholson et al. 2006:2.

Anolis holotropis Boulenger, 1895:522 (holotype unknown, type locality: "Province Matto Grosso, Brazil").

Norops sladeniae Boulenger, 1903:69 (holotype unknown, type locality: "Chapadá, Matto Grosso" = Chapada dos Guimarães, Mato Grosso, Brasil, according to Vanzolini and Williams, 1970).

Anolis steinbachi Griffin, 1917:308 (holotype CM 988, type locality "Provincia del Sara, Bolívia").

Norops marmorata Amaral, 1932:63 (holotype MZUSP 737, type locality "Jaguará, Rio Grande, Minas Gerais, Brasil').

Anolis chrysolepis meridionalis; Hellmich, 1960:22 (partim, according to Vanzolini and Williams, 1970).

Norops meridionalis; Nicholson 2002:97.

Abbreviated Description. Maximum SVL $56 \mathrm{~mm}$. Specimens analyzed presented vertebral scales anteriorly small, keeled, posteriorly increasing in size and forming a gradual transition toward the granules on flanks; they do not form rows of enlarged scales along dorsum. The neotype description provided by Motte and Cacciali (2009) states that vertebral scales form eight rows of enlarged scales along back that are distinctly larger than scales on the flanks. Scales on upper arm keeled, markedly larger than 
vertebral scales. Scales on snout anteriorly weakly to distinctly keeled, uni- or multicarinate and slightly larger than the flat posterior scales. Supraorbital semicircles with enlarged, weakly keeled scales. Supraocular region with a group of distinctly enlarged scales surrounded posteriorly and laterally by granules and anteriorly by smaller scales. Interparietal scale distinctly larger than adjacent scales. Loreals 6-7; canthals 5-6; 8-10 scales between second canthals; 01 scales between supraorbital semicircles; 0 2 scales between supraorbital semicircles and interparietal, postmentals 5-8 (Fig. 9F).

Color in Preservative. No sexual dimorphism in color pattern observed. Dorsal color usually grayish-brown, with a light cream, sometimes tending to reddish or light-orange, vertebral band. Dark brown V-shaped lines (apex directed posteriorly) may be present, as well as dark-brown irregular figures and spots across the limbs and in paravertebral region. A pair of subtriangular dark spots on sacral region frequently present.

Dewlap Color in Life and Preservative. When extended, dewlap skin in preservative blue or grayish-blue in center and pale or cream along rim, with light or dark scales. When not extended, grayish-blue laterally, with the center cream or beige. In life, dewlap skin deep blue in center and orange to pale yellow along rim. Scales may be darker on the center, tending to cream or beige on the border, changing to orange or pale yellow on anterior base of dewlap, along rim (Fig. 8F). Langstroth (2006) presented a dewlap photo of a male $A$. meridionalis from near the Zapocós Reservoir in Bolivia showing a deep blue skin with irregular grayish lines and light or dark scales, tending to grayish-green along rim.

Comparisons with the Other Species from the A. chrysolepis Species Group. Anolis meridionalis is sympatric with A. brasiliensis, of which it can be distinguished mainly by the digital dilatations on phalanx ii and iii, which are continuous with scales under phalanx $\mathrm{i}$ and do not form the prominent border observed in A. brasiliensis. Anolis meridionalis can also be distinguished from
A. brasiliensis by smaller body size (A. meridionalis reaches $56 \mathrm{~mm}$, whereas $A$. brasiliensis reaches $69 \mathrm{~mm}$ ), by the smaller number of scales between supraorbital semicircles (0-1 in A. meridionalis and 0-3 in A. brasiliensis), by the smaller number of scales between supraorbital semicircles and interparietal (1-4 in A. brasiliensis and 0-2 in A. meridionalis), and by the smaller number of fourth finger and toe lamellae (15-20 and 25-32, respectively, in A. brasiliensis, 10-12 and 18-24 in A. meridionalis). Besides these morphological differences, these species do not occur in the same habitat: A. meridonalis is commonly found in open areas densely covered by grass in Brazilian Cerrado (Vanzolini and Williams, 1970), whereas A. brasiliensis is a typical inhabitant of gallery forests in the same biome (Vitt et al., 2008). Vitt et al. (2008: 146) found "only two specimens of $A$. brasiliensis outside of forested habitat in typical Cerrado, and both were inside termite nests and inactive."

Distribution. Central Brazil, Paraguay, and Bolivia.

\section{Identification Key to the Species of} THE ANOLIS CHRYSOLEPIS GROUP

1a. Digital dilatations under phalanx ii and iii are continuous with scales under phalanx i, not forming a prominent border; dewlap skin blue or grayish-blue in center and orange to yellowish-orange (it can be pale or cream in preserved specimens) along rim, with light or dark scales ..................... A. meridionalis

1b. Digital dilatations under phalanx ii form a prominent border over scales under phalanx I

2a. A weakly to distinctly double row of enlarged vertebral scales from nape to base of tail; scales on upper arm larger than vertebral scales 
2b. Vertebral area with slightly or distinctly enlarged scales, of which the two vertebral rows may be larger than adjacent ones; scales on upper arm smaller than, to sub equal to, vertebral scales

3a. A double row of weakly enlarged vertebral scales; scales on upper arm slightly larger than vertebral scales; dewlap red along rim (it can be pale in some specimens), with red or blackish scales, and blue with light scales in the center .................... A. scypheus

3b. A double row of distinctly enlarged vertebral scales from nape to base of tail; scales on upper arm distinctly larger than vertebral scales

4a. Supraorbital semicircles with enlarged, keeled scales, forming a pronounced ridge in some specimens; supraocular scales with a group of enlarged scales, surrounded in all their extension by distinctly smaller scales; dewlap skin red, but in preserved specimens it usually appear as pale, with light scales ........ A. planiceps

4b. Supraorbital semicircles with enlarged and generally smooth scales; most supraocular scales large, grading laterally into smaller scales; dewlap skin in preserved specimens blue or grayish-blue with light or grayish scales

A. brasiliensis

$5 \mathrm{a}$. Vertebral area with scales not or only slightly enlarged; interparietal scale distinctly larger than adjacent scales; dewlap skin deep blue or blackish-blue with light and grayish scales ...... A. bombiceps

5 b. Vertebral area with scales slightly to distinctly enlarged; interparietal subequal to or slightly larger than adjacent scales 6a. Vertebral area with scales distinctly enlarged along back, numbers of enlarged rows increasing posteriorly; interparietal subequal to or slightly larger than adjacent scales; male dewlap royal blue, dark blue, or blackish, with light scales or blue scales toward the rim; female dewlap skin pale yellow to orange (it can be pale or cream in preserved specimens), and toward the rim scales may be darker ....... A. chrysolepis

6b. Vertebral area with scales slightly enlarged along back, numbers of enlarged rows increasing posteriorly; interparietal larger than adjacent scales; male dewlap royal blue or blackish-blue, with light scales; female dewlap with a central blue spot, surrounded by a cream area; scales usually light

A. tandai

\section{ACKNOWLEDGMENTS}

We thank M. S. Hoogmoed, T. Mott, D. Mulcahy, I. Sampaio, A. Garda, J. Losos, and A. Aleixo for reviewing the manuscript; J. Losos (Harvard Museum of Comparative Zoology-MCZ), R. Brown (University of Kansas-KU), and R. Brumfield and D. Dittman (Louisiana State UniversityLSUMZ) for the loan of specimens and tissues; K. Kozak for the free pass to the molecular lab; G. D’Angiolella, who helped with map construction; and M. J. Sturaro for help with figure plates. ABD was financially supported by Conselho Nacional de Desenvolvimento Científico e Tecnológico $(\mathrm{CNPq})$ and received an Ernst Mayr Travel Grant to visit the MCZ, where J. Rosado was of great assistance. Work in the herpetological lab of MPEG was supported by PPBIO Amazônia oriental-MCT/MPEG and by $\mathrm{CNPq}$ project $473177 / 2006-4$. TG was supported by NIH grant T32DE007288 from the National Institute of Dental \& Craniofacial Research, TCAP and GRC by 
2010-9 and 302343/88-1) from CNPq. Fieldwork conducted by LJV and J. P. Caldwell was supported by NSF grants DEB 9200779, DEB 9505518, and DEB 0415430; those in Brazil were covered by Portaria MCT 170, de 28/09/94, and by IBAMA permit 073/94-DIFAS. Fieldwork conducted by GRC was covered by IBAMA permit 027/2003-CGFAU/LIC and supported by Programa Nacional de Diversidade Biológica PROBIO/MMA, project "Paisagens e biodiversidade: uma perspectiva integrada para o inventário e conservação da Serra do Cachimbo."

\section{APPENDIX 1 \\ Specimens examined (number of specimens of each species in parentheses).}

Anolis chrysolepis (50). SURINAM: Sipaliwini: Tafelberg Nature Reserve (MCZ R-154861), Nassau: Nassau Plateau (MZUSP 29658), Saramacca: $1 \mathrm{~km}$ from Coppename River (MCZ R-155217). FRENCH GUIANA: Sophie trail S from St. Elie gold pits (MCZ R-77548), lower Matarony River, tributary of Approague River (MCZ R-118644, R-118641, R-110388), Saul (MCZ R-146767), Sinnamary, Petit Sant River (MPEG 15829, 15845). GUIANA: Onora (MCZ R63350), Shudikar-won (MCZ R-65349). BRAZIL: Amapá: Porto Platon (MCZ 85010), Serra do Navio (MCZ R-79146, R-85009; MPEG 19676, 19678, 19679, 19680, 19681, 19682, 19683, 19685, 19686, 19687, 19688, 19690), Mazagão: Rio Maracá (MZUSP 8845, 8846; CHUNB 56761), Laranjal do Jari (CHUNB 56767; MZUSP 83222, 83224), Pará: Aldeia dos índios Tirió (MZUSP 13141), Oriximiná: FLONA SaracáTaquera: Platô Aviso (MPEG 27114, 27217), Platô Almeidas (MPEG 26864), Estação Ecológica GrãoPará, Serra do Acari (MPEG 26573, 27374, 27375, 27376, 27377, 26587, 26578, 26593), Porto Trombetas: Platô Bela Cruz (MPEG 24216), Platô Greig (MPEG 24218), Faro: Floresta Estadual de Faro (MPEG 26597).

Anolis planiceps (72). VENEZUELA: Portuguesa (MCZ R-176492, R-176491, R-176493, R176494, R-176495, R-176496): Acarigua: Environs of Agua Blanca (MCZ R-123708), Distrito Federal: Puerto la Cruz (MCZ R-48782), Amazonas: Puerto Ayacucho (MCZ R-58328, R-84073), Sucre: Cunamacoa, San Rafael (MCZ R-48781), Peninsula of Paria, Yacua (MCZ R-43856, R-43860, R-43857, R-43858), Aragua: Palsamencho Parque, HPittier between Portochuelo and Ocumare (MCZ R-101817), Carabobo: Hacienda San Esteban, North of Puerto Cabello (MCZ R-107688), Goaiguaza: Miquija (MCZ R-121759, R121758, R-121762, R-121760, R-121757), Salon: Las Quiguas (MCZ R-121753, R-81302), Falcón: Acosta, Pauji, (MCZ R-49035, R-48723, R-49037, R-48725,
R-48724, R-49036), Riecito (MCZ R-49050), Miranda: Guatapo (MCZ R-100438), Bolivar: Arabupu, Mt. Roraima (MCZ R-34868). TRINIDAD: Nariva Swamp, Cascadoux Trace (MCZ R-60800), Huevas Id. (MCZ R-100119), Sangre Grande: Toco (MCZ R10746, R-10747), La Seiva (MCZ R-8998, R-8999, R9000), Trinidad: Chacachacare (MCZ R-100118), Maruga (MCZ R-31495), Palmiste: $3 \mathrm{~km} \mathrm{~S}$ San Fernando (MCZ R-85011, R-85012, R-85013, R85014 , R-85015, R-85016, R-85017, R-85018, R100120, R-100121, R-100122, R-81303, R-81304, R81501, R-85474, R-85475, R-85473). BRAZIL: Amazonas: Serra da Neblina (MCZ R-86763), Manaus: Reserva Ducke (MCZ R-92682), Camp Gavião, approx. $100 \mathrm{~km} \mathrm{~N}$ of Manaus (MCZ R-168987). GUYANA: Pomeroon-Supenaam: Dawa (MCZ R-123745), Cuyuni-Mazaruni: Kaburi, 30 miles from Bartica (MCZ R-81306), Mazaruni River (MCZ R-39690), Kamakusa (MCZ R-65352).

Anolys scypheus (49). PERU: Loreto: (KU 222147), Rio Pacaya, Cahuana (MCZ R-160775), Galicia: west bank of Rio Tapiche (MCZ R-157245), Pampa Hermosa: near mouth Cushcbatey River (MCZ R-57369, R-57373, R-57372), Amazonas: Mouth of R.Santiago Maranon (MCZ R-57371), Ucayali: River Tamaya (MCZ R-57374), Madre de Dios: Cocha Cashu, NW of mouth of Rio Manu (MCZ R-178177). ECUADOR: Napo: Trail from Laguna Taracoa, S bank Rio Napo, $30 \mathrm{~km}$ downriver from Coca (MCZ R154571), Hacienda 'Primavera' N bank Rio Napo 30 km from Coca (MCZ 92612, 154567, 154568), Prov. S side of Rio Napo, $6.5 \mathrm{~km}$ ESE of Puerto Misahualli, at La Cruz Blanca on ASuarez's land (MCZ R-171889), Sucumbios: Santa Cecilia (MCZ R-92601, R-92602, R-92603, R- 92604, R-92605, R-92608), Santa Cecilia, Rio Agvaratis (MCZ R-100010), Limon Cocha (MCZ R-156822, R-85098, R-85099, R-85100, R-85101, R92610, R-92611, R-92612), Chimborazo: Riobamba (MCZ R-29290). COLOMBIA: Meta: Villavicencio: San Martin (MCZ R-32309, R-32310, R-32312, R32313, R-32314, R-32315, R-32317), Bairro Povenir (MZUSP 36099, 36100). BRAZIL: Amazonas: Acanauí (MZUSP 47213, 47214), Rio Japurá: Serrinha (MZUSP 46793, 46794), Costa da Altamira (MZUSP 47301, 47302, 47303); Lago Amanã (MZUSP 60462).

Anolis tandai (96). BRAZIL: Rondônia: Espigão do Oeste (MPEG 21479, 21483, 21488, 21899), Amazonas: Estirão do Equador (MPEG 901), Rio Urucu (holotype: MPEG 15850), Benjamin Constant (paratypes: MPEG 15933, 15938, 15949, 15986, 15987, 15995; MZUSP 15898), Madeireira Sheffer, Rio Ituxi (MPEG 20372, 20473, 20474), Careiro da Várzea, estrada para Altazes (MPEG 18918, 18920, 18928, 18931, 18934, 18935), Tapauá (MZUSP 37763, 37764 , 37765), Beruré (MZUSP 38101, 38102), Novo Aripuanã (MZUSP 42400), Borba (MZUSP 41077, 9145), Rio Juruá (MZUSP 700), Barreira do Matupiré, Rio Madeira, (MZUSP 42150), Maués, Bragança/São Tomé, Rio Paraconi (MPEG 27673, 27674, 27675, 27676), Acre: Rio Juruá, approx. $30 \mathrm{~km}$ North of Porto Walter of Walter (MPEG 20655, 20656, 20658, 20659, 
20662, 20663, 20665, MZUSP 53270, 53271, 53272), Alto Purus (MZUSP 2413, 2514), Seringal Santo Antônio, próximo a Manoel Urbano (MZUSP 32097), Parque Nacional Serra do Divisor, Estirão do Panela (MZUSP 88656), Estirão do Equador (MZUSP 899), Pará: Parque Nacional da Amazônia, Itaituba (MPEG 21986, 21987, 21988, 21989, 21990, 21991), Parque Nacional da Amazônia, Uruá (MZUSP 52533, 52536, 52538, 52539), Cachoeira da Montanha (MZUSP 53657, 53658), Buburé (MZUSP 53692, 53693, 53695), Barreirinha, próximo a São Luis, Rio Tapajós (MZUSP 20679), Mato Grosso: Aripuanã (MZUSP $82590,82585,82589,82587,82591,82593,82586$, $82592,82588,82594,81502,81512,81501,81520$, $81505,81497,81508,81514,81494,81491)$, Juruena (MZUSP 82402, 82404, 82397, 82403, 82400). PERU: Loreto: Rio Orosa (MZUSP 56658), Alto Curanja, Igarapé Champuia (MZUSP 3324, 3324).

Anolis brasiliensis (116). BRAZIL: Mato Grosso: Barra do Tapirapés (holotype: MZUSP 10319, paratypes: MCZ R-98284, R-98285, R-98286, R-98287, R98288, R-98289), Porto Alegre do Norte (CHUNB 47842),Vila Rica (MZUSP 82874, 82884, 82882), Tocantins: Caseara (CHUNB 44989, 44992, 44499, 45000, 45009, 45036, 45028, 45026, 45022, 45030), Pium (CHUNB 24754, 24756), Palmas (CHUNB 25082, 24216, 11521, 11522, 24215, 16947, 25092, 11520, 24262, 15230, 16142, 16948), Peixe (CHUNB $52471,52472,52474)$, Porto Alegre do Tocantins (CHUNB 38918), Porto Nacional (CHUNB 47741, 47742, 47740), Mateiros (CHUNB 27161, 27158, 27162), Usina Hidroelétrica Luis Eduardo Magalhães (MZUSP 95466, 95467), Goiás: São Domingos (CHUNB 35282, 35257, 35288, 35319, 35285, 35314, $43823,35315,35311,35258,43824,43832,33020$ ), Minaçu (CHUNB 11019, 11021, 10967, 10983, 49706, 48617, 10987, 49703, 10986, 10970, 10999, 08655, 29309), Colinas do Sul (CHUNB 50396, 50393, 50395, 44694), Valparaiso (CHUNB 08556, 08555), Luziânia (CHUNB 47427, 43408, 40865, 43407, 47426), Três Ranchos (CHUNB 44740), Goiânia (CHUNB 57318), Minas Gerais: Unaí (CHUNB 30888, 32873, 32867, 36287), Distrito Federal: Brasilia (CHUNB 49614), Piauí: Ribeiro Golçalves (CHUNB 57028), Maranhão: Carolina (CHUNB 51972, 51973, 51974, 51975), Gancho do Arari (MZUSP 60682), Pará: Novo Progresso (CHUNB 34542), Parauapebas (CHUNB 08855, 11132), Canaã dos Carajás (MPEG 25166), Itaituba, Jacareacanga (CHUNB 56398), Ceará: Arajara (MZUSP 51698, 51699, 51703, 51706), São Paulo: Bueno de Andrade (MZUSP 4384), Ibarra (MZUSP 4487), Itapura (MZUSP 551).

Anolis meridionalis (9). BRAZIL: Minas Gerais: Paracatu (CHUNB 26140, 26146), Buritizeiro (CHUNB 44522), Rondônia: Vilhena (CHUNB 11715), Tocantins: Palmas (CHUNB 12022, 12026), Goiás: Luziânia (CHUNB 43404, 43405), Distrito Federal: Brasilia (CHUNB 43282).

Anolis bombiceps (11). PERU: Loreto (MZUSP $13135,131137,13138)$, N.A. $1.5 \mathrm{~km} \mathrm{~N}$ of Teniente Lopez, 310 (KU 222145). COLOMBIA: Amazonas:
6 km NW of Leticia (MCZ R-112267). ECUADOR: Pastaza: Conambo (MZUSP 13140). BRAZIL: Amazonas: Apuí (CHUNB 38340); São Gabriel da Cachoeira: Missão Taraquá, Rio Uapés (MPEG 17819), Uatumã (MZUSP 17439), Igarapé Belém, Rio Solimões (MZUSP R-13026, 13027).

Anolis onca (1). VENEZUELA: Falcón: Rio Seco on Caribean Sea, between Urumaco and Coro (MCZ R-132736).

Anolis lineatus (1). NETHERLANDS ANTILLES: Curaçao: Cos Cora (MCZ R-83027).

Anolis sagrei sagrei (1). JAMAICA: Westmoreland: Savanna La Mar (MCZ R-161754).

Anolis auratus (1). COLOMBIA: Magdalena: Pozo Colorado, $11 \mathrm{~km} \mathrm{~W}$ of Santa Maria (MCZ R104546).

\section{LITERATURE CITED}

Amaral, A. 1932. Estudos sobre lacertílios neotropicais. I. Novos gêneros e espécies de lagartos do Brasil. Memórias do Instituto Butantan 7: 51-74.

Amaral, A. 1937. Herpetological collection from Central Brazil. Compte Rendus XIIe. Congrès International de Zoologique. Lisbon 1935: 17201732 .

Avila-Pires, T. C. S. 1995. Lizards of Brazilian Amazonia (Reptilia: Squamata). Zoologische Verhandelingen Leiden, 299: 1-706.

Avila Pires, T. C. S., M. S. Hoogmoed, and W. A. Rocha. 2010. Notes on the herpetofauna of northern Pará, Brazil: a forgotten part of the Guianan Region, I. Herpetofauna. Boletim Museu Paraense Emílio Goeldi. Ciências Naturais 5: 13112

Avila Pires, T. C. S., L. J. Vitt, S. S. Sartorius, and P. A. Zani. 2009. Squamata (Reptilia) from four sites in southern Amazonia, with a biogeographic analysis of Amazonian lizards. Boletim Museu Paraense Emílio Goeldi. Ciências Naturais 4: 99118.

Avise, J. C. 2000. Phylogeography: The History and Formation of Species. Cambridge: Harvard University Press.

Avise, J. C., D. Walker, and G. C. Johns. 1998. Speciation durations and Pleistocene: effects on vertebrate phylogeography. Proceedings of the Royal Society of London. B 265: 1707-1712.

Ballard, J. W., and M. C. Whitlock. 2004. The incomplete natural history of mitochondria. Molecular Ecology 13: 729-744.

Barbour, T. 1932. New Anoles. Proceedings of the New England Zoological Club 12: 97-102.

Barrowclough, G. F., and R. M. Zink. 2009. Funds enough and time: mtDNA, nuDNA and the discovery of divergence. Molecular Ecology 18: 2934-2936.

Beebe, W. 1944 Field notes on the lizards of Kartabo, British Guiana, and Caripito, Venezuela. Part 2. Iguanidae. Zoologica 29: 195-216. 
Boettger, O. 1885a. Liste von Reptilien und Batrachiern aus Paraguay. Zeitschrift für Naturwissenschaften, Halle 58: 213-248.

Boettger, O. 1885b. Berichtigung der Liste von Reptilien und Amphibien am Paraguay von Dr. O. Boettcher. Zeitschrift für Naturwissenschaften, Halle 58: 436-437.

Boettger, O. 1895. Description of a new Anolis from Brazil. Annals and Magazine of Natural History 15: 522-523.

Boettger, O. 1903. List of the batrachians and reptiles collected by M.A. Robert at Chapadá, Matto Grosso, and presented by Mrs. Percy Sladen to the British Museum. (Percy Sladen Expedition to Central Brazil). Proceedings of the Zoological Society of London 2: 69-70.

Boulenger, G. A. 1885. Catalogue of the Lizards in the British Museum (Natural History). Vol. 2. London: Taylor \& Francis.

Brandley, M. C., A. Schmitz, and T. W. Reeder, 2005. Partitioned Bayesian analysis, partition choice, and the phylogenetic relationships of scincid lizards. Systematic Biology 54: 373-390.

Bull, J. J., J. P. Huelsenbeck, C. W. Cunningham, and D. L. Swofford. 1993. Partitioning and combining data in phylogenetic analysis. Systematic Zoology 42: $384-397$.

Burnaby, T. P. 1966. Growth-invariant discriminant functions and generalized distances. Biometrics 22 96-110.

Cope, E. D. 1864. Contributions to the herpetology of tropical America. Proceedings of the Academy of Natural Sciences of Philadelphia 16: 166-181.

Cope, E. D. 1876. Report on the reptiles brought by Professor James Orton from the middle and upper Amazon, and western Peru. Journal of the Academy of Natural Sciences of Philadelphia 8: 159-183.

Cunha, O. R. 1961. Lacertílios da Amazônia II. Os lagartos da Amazônia brasileira, com especial referência aos representados na coleção do Museu Goeldi. Boletim do Museu Paraense Emílio Goeldi 39: 1-189.

Cunha, O. R, F. P. Nascimento, and T. C. S. AvilaPires. 1985. Os Répteis da área de Carajás, Pará, Brasil (Testudines e Squamata). I. Publicações Avulsas do Museu Paraense Emílio Goeldi 40: 9-92.

DE Queiroz, K. 1998. The general lineage concept of species, species criteria, and the process of speciation: a conceptual unification and terminological recommendation. In D. J. Howard and S. H. Berlocher (eds.), Endless Forms: Species and Speciation. New York: Oxford University Press.

DE Queiroz, K. 1999. The general lineage concept of species and the defining properties of the species category, pp. 49-89. In R. A. Wilson (ed.), Species: New Interdisciplinary Essays. Cambridge, Massachusetts: MIT Press.

DE QueIroz, K. 2005a. Ernst Mayr and the modern concept of species. Proceedings of the National Academy of Science 102: 6600-6607.
DE QueIroz, K. 2005b. A unified concept of species and its consequences for the future of taxonomy. Proceedings of the California Academy of Science 18: 196-215.

DE QueIroz, K. 2007. Species concept and species delimitation. Systematic Biology 56: 879-886.

Dixon, J. R., and P. Sorni. 1986. The reptiles of the upper Amazon Basin, Iquitos Region, Peru. Milwaukee: Milwaukee Public Museum Contributions in Biology and Geology 4: 1-58.

Duméril, A. M. C., and G. Bibron. 1837. Erpétologie Général ou Histoire Naturelle compléte des Reptiles. Vol. 4. Paris: Librairie Encyclopédique de Roret.

Felsenstein J. 1978. Cases in which parsimony or compatibility methods will be positively misleading. Systematic Zoology 27: 401-410.

Felsenstein, J. 1985. Confidence limits on phylogenies, an approach using the bootstrap. Evolution 39: 783-791.

Fenwick, A. M., R. L. Gutberlet, TB Jr, J. A. Evans, and C. L. Parkinson. 2009. Morphological and molecular evidence for phylogeny and classification of South American pitvipers, genera Bothrops, Bothriopsis, and Bothrocophias (Serpentes: Viperidae). Zoological Journal of the Linnean Society 156: $617-640$.

Forbes, E. 1846. On the connection between the distribution of the existing fauna and flora of the British Isles, and the geological changes which have affected their area, especially during the epoch of the northern drift. Memoirs of Geological Survey, Great Britain 1: 336-432.

Gamble, T., A. M. Simons, G. R. Colli, and L. J. Vitt. 2008. Tertiary climate change and the diversification of the Amazonian gecko genus Gonatodes (Sphaerodactylidae, Squamata). Molecular Phylogenetics and Evolution 46: 269-277.

Gascon, C., and O. S. Pereira. 1993. Preliminary checklist of the herpetofauna of the upper Rio Urucu, Amazonas, Brazil. Revista Brasileira de Zoologia 10: 179-183.

Glor, R. E., L. J., VitT, and A. Larson. 2001. A molecular phylogenetic analysis of diversification in Amazonian Anolis lizards. Molecular Ecology 10: 2661-2668.

Goeldi, E. A. 1902. Lagartos do Brasil. Boletim do Museu Paraense 3: 499-560.

Grau, E. T., S. L. Pereira, L. F. Silveira, E. Höfling, and A. Wajntal. 2005. Molecular phylogenetics and biogeography of Neotropical piping guans (Aves: Galliformes): Pipile Bonaparte, 1856 is synonym of Aburria Reichenbach, 1853. Molecular Phylogenetics and Evolution 35: 637-645.

Graybeal, A. 1998. Is it better to add taxa or characters to a difficult phylogenetic problem? Systematic Biology 47: 9-17.

Griffin, L. E. 1917. A list of the South American lizards in the Carnegie Museum, with descriptions of four new species. Annals of the Carnegie Museum 2 : 304-320. 
Guichenot, A. 1855. Reptiles, pp. 1-95. In F. de Castelnau (ed.), Animaux nouveaux ou rares recueillis pendant l'expédition dans les parties centrales de l'Amérique du Sud, de Rio de Janeiro a Lima, et de Lima au Para; exécutée par ordre du gouvernement français pendant les années 1843 a 1847, sous la direction du Comte Francis de Castelnau. Paris: Chez P. Bertrand, Libraire Éditeur.

Haffer, J. 1969. Speciation in Amazonian forest birds. Science 165: 131-137.

Hellmich, W. 1960. Die Sauria der Grand Chaco und seiner Randgebiete. Abhandlungen Bayerische Akademie der Wissenschaften (N.F.), 101: 1-131.

Hoogmoed, M. S. 1973. Notes on the Herpetofauna of Surinam IV. The Lizards and Amphisbaenians of Surinam. Biogeographica, 4. The Hague: Dr. W. Junk Publishers.

Hoogmoed, M. S., and T. C. S. Avila-Pires. 1989. Observations on the nocturnal activity of lizards on a marshy área in Serra do Navio, Brazil. Tropical Zoology 2: 165-173.

Hoogmoed, M. S., and T. C. S. Avila-Pires. 1991. Annotated checklist of the herpetofauna of Petit Saut, Sinnamary River, French Guiana. Zoologische Verhandelingen Leiden 65: 53-88.

Hudson, R. R., and M. Turelli. 2003. Stochasticity overrules the "three-times rule": genetic drift, genetic draft, and coalescence times for nuclear loci versus mitochondrial. Evolution 57: 182-190.

Huelsenbeck, J. P., and F. Ronquist. 2001. MRBAYES: Bayesian inference of phylogeny. Bioinformatics 17: 754-755.

Huelsenbeck, J. P., F. Ronquist, R. Nielson, and J. P. Bollback. 2001. Bayesian inference of phylogeny and its impact on evolutionary biology. Science 294: 2310-2314.

Icochea, J., E. Quispitupac, A. Portilla, and E. Ponce. 2001. The amphibian and reptile fauna of the lower Urubamba region, Peru. In F. Dallmeier, A. Alonso, and P. Campbell (eds.), Biodiversity of the Lower Urubamba Region, Peru. SIMAB series 7. Washington, DC: Smithsonian Institution/MAB Biodiversity Program.

ICZN. 2010. OPINION 2256 (Case 3446) Anolis chrysolepis Duméril \& Bibron, 1837 (Reptilia, Squamata): precedence given over Draconura nitens Wagler, 1830. Bulletin of Zoological Nomenclature 67: 266-268.

Jolicoeur, P. 1963. Multivariate generalization of allometry equation. Biometrics 19: 497-499.

Jukes, T. H. 1987. Transitions, transversions, and the molecular evolutionary clock. Journal of Molecular Evolution 26: 87-98.

Kumar, S., M. Nei, J. Dudley, and K. Tamura. 2008. MEGA: a biologist-centric software for evolutionary analysis of DNA and protein sequences. Briefings in Bioinformatics 9: 299-306.

Langstroth, R. 2006. Notas sobre Anolis meridionalis Boettger, 1885 (Squamata: Iguania: Polychrotidae) en Bolivia y comentarios sobre Anolis steinbachi. Kempffiana 2: 154-172.
Lartillot, N., H. Brinkmann, and H. Philippe. 2007. Suppression of long-branch attraction artifacts in the animal phylogeny using a site-heterogeneous model. BMC Evolutionary Biology 7: 1-14.

Lemmon, A. R., and E. C. Moriarty. 2004. The importance of proper model assumption in Bayesian phylogenetics. Systematic Biology 53: 265-277.

Macey, J. R., J. A. Schulte, N. B. Ananjeva, A. Larson, N. Rastegar-Pouyani, S. M. Shammakov, and T. J. Papenfuss. 1998. Phylogenetic relationships among agamid lizards of the Laudakia caucasia species group: testing hypotheses of biogeographic fragmentation and an area cladogram for the Iranian Plateau. Molecular Phylogenetics and Evolution 10: 118-131.

Macey, J. R., Y. Wang, N. B. Ananjeva, A. Larson, and T. J. Papenfuss. 1999. Vicariant patterns of fragmentation among gekkonid lizards of the genus Teratoscincus produced by the Indian collision: a molecular phylogenetic perspective and an area cladogram for Central Assia. Molecular Phylogenetics and Evolution 12: 320-332.

Maddison, W. P. 1997. Gene trees in species trees. Systematic Biology 46: 523-536.

MadDison, W. P., and L. L. Knowles. 2006. Inferring phylogeny despite incomplete lineage sorting. Systematic Biology 55: 21-30.

Maddison, W. P., and D. R. Maddison. 1992. MacClade Version 3: Analysis of Phylogeny and Character Evolution. Sunderland Massachusetts: Sinauer Associates.

Martins, M. 1991. The lizards of Balbina, central Amazonia, Brazil: a qualitative analysis of resource utilization. Studies on Neotropical Fauna and Environment 26: 179-190.

Mitchell, A., C. Mitter, and J. C. Regier. 2000. More taxa or more characters revisited: combining data from nuclear protein-encoding genes for phylogenetic analyses of Noctuoidea (Insecta: Lepidoptera). Systematic Biology 49: 202-224.

Motte, M. and P. Cacciali. 2009. Descripción de un neotipo para Anolis meridionalis Boettger, 1885 (Sauria: Polychrotidae). Cuadernos de Herpetología 23: 19-24.

Myers, C. W. 2008. Anolis chrysolepis Duméril \& Bibron, 1837 (Reptilia, Squamata): proposed precedence over Draconura nitens Wagler, 1830. Bulletin of Zoological Nomenclature 65: 205-213.

Myers, C. W., and M. A. Donnelly. 2008. The summit herpetofauna of Auyantepui, Venezuela: report from the Robert G. Goelet American MuseumTerramar Expedition. Bulletin of the American Museum of Natural History 308.

NeI, M., and W. H. LI. 1979. Mathematical model for studying genetic variation in terms of restriction endonucleases. Proceedings of National Academy of Sciences 76: 5269-5273.

Nicholson, K. E. 2002. Phylogenetic analyzes and a test of the current infrageneric classification of Norops (Beta Anolis). Herpetological Monographs 16: 93120 
Nicholson, K. E., R. E. Glor, J. J. Kolbe, A. Larson, S. B. Hedges, and J. B. Losos. 2005. Mainland colonization by island lizards. Journal of Biogeography 32: 929-938.

Nicholson, K. E., L. J Kolbe, and J. B. Losos. 2007. Evolution of Anolis lizard dewlap diversity. PLoS ONE 2: e274.

Nicholson, K. E., A. Mijares-Urrutia, and A. Larson. 2006. Molecular phylogenetics of the Anolis onca series: a case history in retrograde evolution revisited. Journal of Experimental Zoology (Molecular and Developmental Evolution) 306: 450459.

Nylander, J. A. A., F. Ronquist, J. P. Huelsenbeck, and J. L. Nieves-Aldrey. 2004. Bayesian phylogenetic analysis of combined data. Systematic Biology 53: $47-67$.

Nylander, J. A. A., J. C. Wilgenbusch, D. L. Warken, and D. L. Swofford. 2008. AWTY (are we there yet?): a system for graphical exploration of MCMC convergence in Bayesian phylogenetics. Bioinformatics 24: 581-583.

Oliver, P. M., M. Adams, M. S. Lee, M. N Hutchinson, and P. Doughty. 2009. Cryptic diversity in vertebrates: molecular data double estimates of species diversity in a radiation of Australian lizards (Diplodactylus, Gekkota). Proceedings of Biological Sciences 276: 2001-2007.

O’Shea, M. 1989. The herpetofauna of Ilha de Maracá State of Roraima, northern Brazil. Proceedings of the 1988 U.K. Herpetological Societies, Symposium on Captive Breeding Reptiles: 51-72.

Peters, J. A., and R. Donoso-Barros. 1970. Catalogue of the Neotropical squamata. Part II. Lizards and amphisbaenians. United States National Museum Bulletin 297: 1-293.

PosadA, D. 2008. jModelTest: phylogenetic model averaging. Molecular Biology and Evolution 25: $1253-1256$

Quinn, G. P., and M. J. Keough, 2002. Experimental Design and Data Analysis for Biologists. Cambridge, UK: Cambridge University Press.

R Development Core Team. 2009. R: A Language and Environment for Statistical Computing. Vienna, Austria: R Foundation for Statistical Computing.

Rambaut, A., and A. J. Drummond. 2009. Tracer v1.5. Available from http://beast.bio.ed.ac.uk.

Rodriguez-Robles, J. A., T. Jeskova, and M. A. García. 2007. Evolutionary relationships and historical biogeography of Anolis desechensis and Anolis monensis, two lizards endemic to small islands in the Caribbean Sea. Journal of Biogeography 34: 1546-1558.

Rohlf, F. J., and F. L. Bookstein. 1987. A comment on shearing as a method for "size correction." Systematic Zoology 36: 356-367.

Roze, J. A. 1958. Los reptiles del Chimantá Tepui (Estado Bolivar, Venezuela) colectados por la expedicion botanica del Chicago Natural History Museum. Acta Biologica Venezuelica 2: 299314.
Rubin, D. B. 1996. Multiple imputation after 18+ years. Journal of the American Statistical Association 91: 473-489.

Santos-JR, A. P., J. G. Frota, and F. R. V. Ribeiro. 2007. Reptilia, Squamata, Polychrotidae, Anolis nitens tandai: distribution extension, new State record, and geographic distribution map. Check List 3: 9-10.

Savage, J. M., and C. Guyer. 1989. Infrageneric classification and species composition of the anole genera, Anolis, Ctenotus, Dactyloa, Norops and Semiurus (Sauria: Iguanidae). Amphibia-Reptilia 10: $105-116$.

Savage, J. M., and C. Guyer. 1991. Nomenclatural notes on anoles (Sauria: Polychridae): stability over priority. Journal of Herpetology 25: 365-366.

SchaAd, E. W., and S. Poe. 2010. Patterns of ecomorphological convergence among mainland and island Anolis lizards. Biological Journal of the Linnean Society 101: 852-859.

Shimodaira, H. 2001. CONSEL: for assessing the confidence of phylogenetic tree selection. Bioinformatics 17: 1246-1247.

Shimodaira, H.. 2002. An approximately unbiased test of phylogenetic tree selection. Systematic Biology 51: 492-508.

Shimodaira, H., and M. Hasegawa. 1999. Multiple comparisons of log-likelihoods with applications to phylogenetic inference. Molecular Biology and Evolution 16: 1114-1116.

Somers, K. M. 1986. Multivariate allometry and removal of size with principal components analysis. Systematic Zoology 35: 359-368.

Stamatakis, A. 2006. RAxML-VI-HPC: maximum likelihood-based phylogenetic analyses with thousands of taxa and mixed models. Bioinformatics $\mathbf{2 2}$ : 2688-2690.

Swofford, D. L. 2001. PAUP. Phylogenetic Analysis Using Parsimony (and Other Methods). Version 4.0. Sunderland, Massachusetts: Sinauer Associates.

Tabachnick, B. G., and L. S. Fidell. 2001. Using Multivariate Statistics. Needham Heights, Massachusetts: Allyn and Bacon.

Troschel, F. H. 1848. Amphibien. In R. Schomburgk (ed.), Reisen in British Guiana. In Den Jahren. Im Auftrag Sr. Majestat des Konigs von Preussen ausgefuhrt von Richard Schomburgk. 3: 18401844. Versucheiner fauna und flora von British Guiana.

Van Buuren, S., J. P. L. Brand, C. G. M. GroothuisOudshoorn, and D. B. Rubin. 2006. Fully conditional specification in multivariate imputation. Journal of Statistical Computation and Simulation 76: 1049-1064.

Vanzolini, P. E., and E. E. Williams. 1970. South American anoles: the geographic differentiation and evolution of the Anolis chrysolepis species group (Sauria: Iguanidae). Part 1 and part 2. Arquivos de Zoologia (São Paulo) 19: 1-124.

Vanzolini, P. E. 1981. The vanishing refuge: a mechanism for ecogeographic speciation. Papéis Avulsos de Zoologia (São Paulo) 34: 251-255. 
Vanzolini, P. E. 1986. Levantamento herpetológico da área do estado de Rondônia sob a influência da rodovia BR 364. Programa Polonoroeste, subprograma Ecologia Animal, Relatório de Pesquisa no. 1. Brasilia: Ministério de Ciência e TécnologiaCNPq.

Vitt, L. J., W. E. Magnussum, T. C. S. Avila-Pires, and A. P. Lima. 2008. Guide to the Lizards of Reserva Adolpho Ducke, Central Amazônia. Manaus: Áttena Design Editorial.

Vitt, L. J., S. S. Sartorius, T. C. S. Avila-Pires, and M. C. Espósito. 2001. Life on the leaf litter: the ecology of Anolis nitens tandai in the brazilian Amazon. Copeia 2001: 401-412.

Vitt, L. J., D. B. Shepard, G. H. C. Vieira, J. P. Caldwell, G. R. Colli, and D. O. Mesquita. 2008. Ecology of Anolis nitens brasiliensis in cerrado woodlands of Cantão. Copeia 2008: 144-153.

VitT, L. J., and P. A. Zani. 1996. Ecology of the South American Lizard Norops chrysolepis (Polychrotidae). Copeia 1996: 56-68.

Wagler, J. G. 1830. Natürliches System der Amphibien, mit vorangehender Classification der Säugthiere und Vögel. Munich: J.G. Cotta.

Werneck, F. P., and. G. R. Colli. 2006. The lizard assemblage from seasonally dry tropical forest enclaves in the Cerrado biome and its association with the Pleistocenic Arc. Journal of Biogeography 33: 1983-1992.

Wiens, J. J., and B. D. Hollingsworth. 2000. War of the iguanas: conflicting molecular and morphology phylogenies and long-branch attraction in iguanid lizards. Systematic Biology 49: 143-149.

Wiens, J. J., and T. A. Penkrot. 2002. Delimiting species using DNA and morphological variation and discordant species limits in spiny lizards (Sceloporus). Systematic Biology 51: 69-91.

Williams, E. E., and P. E. Vanzolini. 1980. Notes and biogeographic comments on anoles from Brasil. Papéis Avulsos de Zoologia, São Paulo 34: 99108.

Yoder, A. D., R. Vilgalys, and M. Ruvolo. 1996. Molecular evolutionary dynamics of cytochrome $b$ in strepsirrhine primates: the phylogenetic significance of third-position transversions. Molecular Biology and Evolution 13: 1339-1350.

Zimmerman, B. L., and M. T. Rodrigues. 1990. Frogs, snakes, and lizards of the INPA-WWF reserves near Manaus, Brazil, pp. 426-454. In A. H. Gentry (ed.), Four Neotropical Rainforests. London: Yale University Press.

Zink, R. M., and G. F. Barrowclough. 2008. Mitochondrial DNA under siege in avian phylogeography. Molecular Ecology 17: 2107-2121. 